\title{
Comparative assessment of GRASP algorithm for a dust event over Granada (Spain) during ChArMEx-ADRIMED 2013 campaign
}

\author{
Jose A. Benavent-Oltra ${ }^{1,2}$, Roberto Román ${ }^{1,2}$, María J. Granados-Muñoz ${ }^{1,2}$, Daniel Pérez-Ramírez ${ }^{1,2}$, \\ Pablo Ortiz-Amezcua ${ }^{1,2}$, Cyrielle Denjean ${ }^{3}$, Anton Lopatin ${ }^{4}$, Hassan Lyamani ${ }^{1,2}$, Benjamin Torres ${ }^{4,5}$, \\ Juan L. Guerrero-Rascado ${ }^{1,2}$, David Fuertes ${ }^{5}$, Oleg Dubovik ${ }^{4}$, Anatoli Chaikovsky ${ }^{6}$, Francisco J. Olmo ${ }^{1,2}$, \\ Marc Mallet ${ }^{3}$, and Lucas Alados-Arboledas ${ }^{1,2}$ \\ ${ }^{1}$ Department of Applied Physics, University of Granada, 18071 Granada, Spain \\ ${ }^{2}$ Andalusian Institute for Earth System Research (IISTA-CEAMA), University of Granada, Autonomous Government of \\ Andalusia, 18006 Granada, Spain \\ ${ }^{3}$ CNRM, Centre National de la Recherche Météorologique (UMR3589, CNRS, Météo-France), Toulouse, France \\ ${ }^{4}$ Laboratoire d'Optique Atmosphérique, Université de Lille 1, Villeneuve d'Ascq, France \\ ${ }^{5}$ GRASP-SAS, Remote sensing developments, LOA/Université Lille-1, Villeneuve d'Ascq, France \\ ${ }^{6}$ Institute of Physics, National Academy of Science, Minsk, Belarus
}

Correspondence to: Jose A. Benavent-Oltra (jbenavent@ugr.es)

Received: 19 June 2017 - Discussion started: 4 July 2017

Revised: 21 September 2017 - Accepted: 13 October 2017 - Published: 17 November 2017

\begin{abstract}
In this study, vertical profiles and columnintegrated aerosol properties retrieved by the GRASP (Generalized Retrieval of Atmosphere and Surface Properties) algorithm are evaluated with in situ airborne measurements made during the ChArMEx-ADRIMED field campaign in summer 2013. In the framework of this campaign, two different flights took place over Granada (Spain) during a desert dust episode on 16 and 17 June. The GRASP algorithm, which combines lidar and sun-sky photometer data measured at Granada, was used to retrieve aerosol properties. Two sun-photometer datasets are used: one co-located with the lidar system and the other in the Cerro Poyos station, approximately $1200 \mathrm{~m}$ higher than the lidar system but at a short horizontal distance.

Column-integrated aerosol microphysical properties retrieved by GRASP are compared with AERONET products showing a good agreement. Differences between GRASP retrievals and airborne extinction profiles are in the range of 15 to $30 \%$, depending on the instrument on board the aircraft used as reference. On 16 June, a case where the dust layer was coupled to the aerosol layer close to surface, the total volume concentration differences between in situ data and GRASP retrieval are 15 and $36 \%$ for Granada and Cerro Poyos retrievals, respectively. In contrast, on 17 June the dust
\end{abstract}

layer was decoupled from the aerosol layer close to the surface, and the differences are around $17 \%$ for both retrievals. In general, all the discrepancies found are within the uncertainly limits, showing the robustness and reliability of the GRASP algorithm. However, the better agreement found for the Cerro Poyos retrieval with the aircraft data and the vertical homogeneity of certain properties retrieved with GRASP, such as the scattering Ångström exponent, for cases with aerosol layers characterized by different aerosol types, shows that uncertainties in the vertical distribution of the aerosol properties have to be considered.

The comparison presented here between GRASP and other algorithms (i.e. AERONET and LIRIC) and with airborne in situ measurements shows the potential to retrieve the optical and microphysical profiles of the atmospheric aerosol properties. Also, the advantage of GRASP versus LIRIC is that GRASP does not assume the results of the AERONET inversion as a starting point.

\section{Introduction}

Atmospheric aerosols play an important role in the Earthatmosphere radiative system due to their interaction with so- 
lar and terrestrial radiation and their role in cloud development and precipitation (Boucher et al., 2013). Uncertainties associated with the interaction of atmospheric aerosols with radiation have been reduced in the last years, but there is still a need for improvement, mainly in those aspects related to their absorption properties (IPCC, 2013). The characterization of aerosol vertical distribution is another point of interest to reduce uncertainties associated with atmospheric aerosol particles, since they can be different near the surface, within the boundary layer and in the free troposphere.

Passive remote sensing offers large advances in aerosol characterization with global sun-photometry networks such as the Aerosol Robotic Network (AERONET; Holben et al., 1998) or lunar and/or star photometry measurements (PérezRamírez et al., 2012; Barreto et al., 2016, 2017). In the last few years, several different inversion methods, based on spectral aerosol optical depth (AOD) measurements, were developed for the retrieval of aerosol microphysical properties such as effective radius $\left(r_{\text {eff }}\right)$ and volume concentration (VC) (e.g. Pérez-Ramírez et al., 2015; Torres et al., 2017). Furthermore, other sophisticated algorithms that use sky radiance measurements were developed for the retrieval of aerosol microphysical properties as well as intensive properties such as single-scattering albedo (SSA), asymmetry parameter and aerosol refractive index (RI) (e.g. Nakajima et al., 1996; Dubovik and King, 2000; Olmo et al., 2006, 2008). Nevertheless, all these algorithms and measurements only provide column-integrated aerosol properties.

Since the 1970s, lidar systems have been widely used to characterize aerosol vertical distributions in order to contribute to reducing the radiative forcing uncertainties associated with the atmospheric aerosol. The most basic systems use only information about the elastic lidar signal to derive backscatter coefficient by aerosol particles but require an assumption about the extinction-to-backscatter ratio (lidar ratio, LR) (Fernald et al., 1972; Klett, 1981, 1985; Fernald, 1984). More advanced systems such as Raman (Ansmann et al., 1992; Whiteman et al., 1992) and HSRL (High Spectral Resolution Lidar) (Shipley et al., 1983; Grund and Eloranta, 1991) are able to provide independent measurements of backscatter and extinction coefficients $(\beta$ and $\alpha$, respectively) without LR assumption. Also, the depolarization measurements are a lidar improvement that provide information about the shape of aerosols and allow us to characterize the aerosol type (Murayama et al., 2004; Miffre et al., 2011; Bravo-Aranda et al., 2013). However, lidar observations dedicated to the aerosol characterization are very scarce compared to the sun-photometer measurements, and many international networks have emerged in the last decades to homogenize and explore such information. This is the case of the global NASA MPLNET network (Micro-Pulse Lidar Network; Lewis et al., 2016) developed for continuous measurements of aerosol and cloud vertical profiles at different sites in the world using standard instrument and data processing algorithms. The EARLINET (European Aerosol
Research LIdar NETwork; Pappalardo et al., 2014) and LALINET (Latin American LIdar NETwork; Guerrero-Rascado et al., 2016) have also been established in order to provide long-term database for the vertical and temporal distribution of aerosols over Europe and Latin America, respectively.

The retrieval of particle vertical microphysical properties from multiwavelength lidar systems is possible by inverting measurements of three aerosol backscatter and two extinction coefficients, known as the $3 \beta+2 \alpha$ configuration, using the algorithms developed by Müller et al. (1999), Böckmann (2001) and Veselovskii et al. (2002). However, $3 \beta+2 \alpha$ measurements are scarce compared with the large database of elastic lidar measurements. In this sense, different inversion methods were recently developed within the framework of EARLINET in order to retrieve vertical profiles of aerosol microphysical properties using combined information of elastic lidar and sun-photometry measurements. These approaches were the LIdar-Radiometer Inversion Code (LIRIC; Chaikovsky et al., 2008, 2012, 2016), which provides vertical distribution of volume concentrations, and the Generalized Aerosol Retrieval from Radiometer and Lidar Combined data (GARRLiC; Lopatin et al., 2013), which also allows the retrieval of SSA and RI. Currently, GARRLiC algorithm is included in the Generalized Retrieval of Atmosphere and Surface Properties inversion code (GRASP; Dubovik et al., 2011). However, very few studies have attempted to evaluate this recently developed inversion algorithm (Lopatin et al., 2013; Bovchaliuk et al., 2016; Torres et al., 2017; Román et al., 2017), and therefore their evaluation under different atmospheric conditions is still necessary.

Field campaigns with state-of-the-art instrumentation offer unique possibilities for the evaluation of new retrievals techniques of particle microphysical and optical properties. Recently, the ADRIMED (Aerosol Direct Radiative Impact on the regional climate in the MEDiterranean region) field campaign, which was part of the international cooperative research program Chemistry-Aerosol Mediterranean Experiment (ChArMEx; Dulac, 2014), was carried out with the main objective of capturing the high complexity of the different aerosol types in the Mediterranean region (Mallet et al., 2016). Several in situ and remote sensing measurements both from surface and on airborne platforms were collected during this campaign using state-of-the-art instrumentation. The measurements were performed at different stations over the western Mediterranean region during summer 2013 to create an updated database of the physical, chemical and optical aerosol properties as well as the vertical distribution of the major "Mediterranean aerosols" (Mallet et al., 2016; Denjean et al., 2016). Data gathered during ChArMEx-ADRIMED campaign give us an excellent opportunity to evaluate the recently developed algorithms for retrieving aerosol microphysical and optical profiles.

In that framework, the main objective of this study is to evaluate the aerosol optical and microphysical proper- 
ties obtained with GRASP during the ChArMEx-ADRIMED field campaign in Granada, Spain. The GRASP configuration evaluated in this study here is the one that combines lidar signals and sun-sky radiance measurements. The paper is structured as follows: Sect. 2 gives a brief description of the experimental site and the instrumentation employed in this study. GRASP and LIRIC codes are described in detail in Sect. 3. The results are discussed in Sect. 4 and, finally, the main conclusions are summarized in Sect. 5.

\section{Site and instrumentation}

\subsection{Experimental site}

The experimental measurements were obtained over Granada (Spain) at the Andalusian Institute for Earth System Research (IISTA-CEAMA) of the University of Granada, Spain $\left(37.16^{\circ} \mathrm{N}, 3.61^{\circ} \mathrm{W} ; 680 \mathrm{ma.s.1}\right.$ ), and at the remote high mountain site Cerro Poyos $\left(37.11^{\circ} \mathrm{N}, 3.49^{\circ} \mathrm{W} ; 1820 \mathrm{~m}\right.$ a.s.1.) located at the Sierra Nevada mountain range, about $12 \mathrm{~km}$ away (horizontally) from IISTA-CEAMA station. Figure 1 shows a map illustrating the distance between the Granada and Cerro Poyos stations. The city of Granada is located in south-eastern Iberian Peninsula and is a non-industrialized medium-sized city with a population around 300000 (twice including the metropolitan area). The city is sited in a natural basin surrounded by mountains with elevations between 1000 and $3500 \mathrm{~m}$ a.s.l. The area is approximately $200 \mathrm{~km}$ from the African continent and approximately $50 \mathrm{~km}$ from the western Mediterranean basin. In Granada, one main source of natural aerosol is the long-range transport of mineral dust particles from North Africa (e.g. Lyamani et al., 2005; Valenzuela et al., 2012a) that reaches the area in lofted layers (Müller et al., 2009; Guerrero-Rascado et al., 2008, 2009; Córdoba-Jabonero et al., 2011) before mixing with the atmospheric boundary layer (Bravo-Aranda et al., 2015) and been detected at the surface in precipitation samples (Calvo et al., 2010). Another natural source is biomass burning particles: fresh smoke (Alados-Arboledas et al., 2011) and longrange transported smoke (Ortiz-Amezcua et. al., 2014, 2017). While the main anthropogenic sources are pollution from $\mathrm{Eu}-$ rope, the Iberian Peninsula and the Mediterranean Sea (Lyamani et al., 2006; Pérez-Ramírez et al., 2016), local sources are mainly road traffic and central heating systems (Lyamani et al., 2012; Titos et al., 2017).

\subsection{Ground-based instrumentation}

Columnar aerosol properties during daytime were obtained by CIMEL CE-318-4 (Cimel Electronique) sun-sky photometers at IISTA-CEAMA and Cerro Poyos sites. The sunphotometer instruments used in this study are operated in the framework of AERONET-RIMA network (Iberian Network for Aerosol Measurements, infrastructure of AERONET) (https://aeronet.gsfc.nasa.gov/). A complete description of

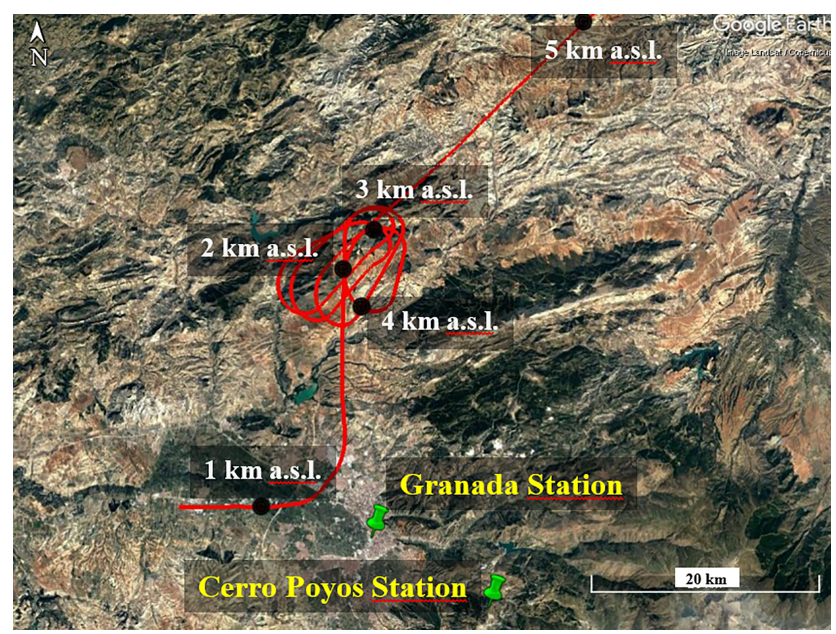

Figure 1. Map illustrating the Granada and Cerro Poyos stations. The red line indicates the trajectory and the black points show the altitude of the aircraft on 17 June.

the instrument can be found in Holben et al. (1998). Briefly, this instrument makes direct solar irradiance measurements at 340, 380, 440, 670, 870 and $1020 \mathrm{~nm}$ and sky radiance measurements at 440, 670, 870 and $1020 \mathrm{~nm}$. Solar direct irradiance measurements are used to calculate the AOD at 340 , $380,440,670,870$ and $1020 \mathrm{~nm}$, with uncertainty of \pm 0.01 for $\lambda>400 \mathrm{~nm}$ and of \pm 0.02 for $\lambda<400 \mathrm{~nm}$ (Holben et al., 1998; Eck et al., 1999). Furthermore, the Ångström exponent $(\mathrm{AE})$, a parameter that describes the spectral dependency of the AOD, is calculated in the range of 440-870 nm. The AE provides an indication of the particle size: small values $(<0.5)$ suggest a predominance of coarse particles, while large values $(>1.5)$ indicate a predominance of small particles (e.g. Dubovik et al., 2002). The solar direct irradiance and sky radiance measurements are used to retrieve aerosol optical and microphysical properties such as columnar particle size distribution (PSD), real and imaginary refractive indices (RRI and IRI) and SSA, using the algorithm of Dubovik et al. (2006). In addition, the inversion code provides other variables such as the VC, $r_{\text {eff }}$ and standard deviation for fine and coarse modes of the retrieved PSD. The uncertainty of the AERONET inversion products is described by Dubovik et al. (2000). Briefly, the uncertainty in the retrieval of SSA is \pm 0.03 for high aerosol load $\left(\mathrm{AOD}_{440}>0.4\right)$ and solar zenith angle $>50^{\circ}$. For measurements with low aerosol load $\left(\mathrm{AOD}_{440}<0.2\right)$, the retrieval accuracy of SSA $(\lambda)$ drops down to 0.02-0.07 (Dubovik et al., 2000). For high aerosol load and solar zenith angle $>50^{\circ}$, errors are about $30-50 \%$ for the imaginary part of the RI. For particles in the size range $0.1<r<7 \mu \mathrm{m}$, errors in PSD retrievals are around 10-35\%, while for sizes lower than $1 \mu \mathrm{m}$ and higher than $7 \mu \mathrm{m}$ retrieval errors rise up to $80-100 \%$. In this work, the AERONET Version 2 Level 2.0 data obtained at Granada and Cerro Poyos during 
Table 1. Instruments on board the ATR-42 aircraft during F30 and F31 flights.

\begin{tabular}{|c|c|c|c|c|c|}
\hline $\begin{array}{l}\text { Parameter } \\
\text { measured }\end{array}$ & Instrument & Abbreviation & Scientific objective & $\begin{array}{l}\text { Nominal size } \\
\text { range }(\mu \mathrm{m})\end{array}$ & $\begin{array}{l}\text { Wavelength } \\
(\mathrm{nm})\end{array}$ \\
\hline \multirow{3}{*}{ Size distribution } & $\begin{array}{l}\text { Forward scattering spectrometer } \\
\text { probe, model } 300, \text { Particle } \\
\text { Measuring Systems }\end{array}$ & FSSP-300 & Coarse mode concentration & $0.28-20$ & 632.8 \\
\hline & $\begin{array}{l}\text { Sky optical particle counter, } \\
\text { model } 1.129 \text {, Grimm Technik }\end{array}$ & GRIMM & Coarse mode concentration & $0.25-32$ & 655 \\
\hline & $\begin{array}{l}\text { Scanning mobility particle sizer, } \\
\text { custom-built }\end{array}$ & SMPS & $\begin{array}{l}\text { Aiken }+ \text { accumulation } \\
\text { mode concentration }\end{array}$ & $0.03-0.4$ & $\mathrm{n} / \mathrm{a}^{*}$ \\
\hline Optical properties & $\begin{array}{l}\text { Photomètre Léger Aéroporté pour } \\
\text { la Surveillance des Masses d'Air }\end{array}$ & PLASMA & $\begin{array}{l}\text { Extinction coefficient, } \\
\text { AOD }\end{array}$ & $\mathrm{n} / \mathrm{a}^{*}$ & $340-2250$ \\
\hline
\end{tabular}

* Not applicable.

ChArMEx-ADRIMED 2013 are used. However, due to the strong limitations imposed by the AERONET inversion algorithm $\left(\mathrm{AOD}_{440}>0.4\right.$ and solar zenith angle $\left.>50^{\circ}\right)$, there was no SSA and RI AERONET Level 2.0 retrievals during the campaign. Thus, for comparing AERONET SSA values with GRASP retrievals, the AERONET Level 1.5 cloud screened data corresponding to AOD $>0.2$ and solar zenith angle $>50^{\circ}$ are used in this study.

The multiwavelength Raman lidar MULHACEN, based on a customized version of LR331D400 (Raymetrics S.A.), is used for obtaining vertical profiles of the atmospheric aerosol properties. This system, located at Granada, was incorporated to EARLINET in April 2005 and at present a contributing station to ACTRIS research infrastructure (Aerosols, Clouds, and Trace gases Research InfraStructure Network; http://actris2.nilu.no/). The system has a monostatic biaxial configuration alignment, pointing vertically to the zenith and uses a pulsed Nd:YAG laser with secondand third-harmonic generators, that emits simultaneously pulses at 1064, 532 and $355 \mathrm{~nm}$. The receiving system consists of several detectors, which can split the radiation according to the three elastic channels at 355, 532 (paralleland perpendicular-polarized; Bravo-Aranda et al., 2013) and $1064 \mathrm{~nm}$; two nitrogen Raman channels at 387 and $607 \mathrm{~nm}$ (shifted signal from radiation at 355 and $532 \mathrm{~nm}$, respectively); and a water vapour Raman channel at $408 \mathrm{~nm}$ (shifted signal from radiation at $355 \mathrm{~nm}$; Navas-Guzmán et al., 2014). More information can be found in Guerrero-Rascado et al. (2008). The aerosol particle backscatter coefficient pro- files obtained from the multiwavelength lidar were obtained by the Klett-Fernald method (Fernald et al., 1972; Fernald, 1984; Klett, 1981, 1985). Total uncertainty in the profiles obtained with Klett method is usually $20 \%$ for $\beta$ and $25-30 \%$ for $\alpha$ profiles (Franke et al., 2001; Preißler et al., 2011). The procedure suggested by Wandinger and Ansmann (2002) was applied to the lidar data to correct the incomplete overlap. Without correction, the complete overlap for this instrument is above $1200 \mathrm{~m}$ a.g.l. (Navas-Guzmán et al., 2011).

\subsection{Airborne measurements}

During the period from 14 June to 4 July 2013, 16 flights were performed in the framework of ChArMEx-ADRIMED over the Mediterranean Basin with the ATR-42 aircraft of SAFIRE (French aircraft service for environmental research; http://www.safire.fr). These flights ascended or descended performing a spiral trajectory during $30 \mathrm{~min}$. Two of these flights (flight number F30 and F31) took place over Granada on 16 and 17 June 2013, respectively. Figure 1 shows the spiral trajectory of F31 flight that is similar to that of F30, covering in both cases the same atmospheric column. Flight details are described by Mallet et al. (2016) and Denjean et al. (2016).

Table 1 summarizes the instrumentation on board the ATR-42 airplane used in this study. The scanning mobility particle sizer (SMPS) with an accuracy of $5 \%$ (Wiedensohler et al., 2012) and the ultra high-sensitivity aerosol spectrometer (UHSAS) with an accuracy of $10 \%$ (Cai et al., 2008) are used for measuring aerosol number size distribution in 
Table 2. Input and output information used for LIRIC and GRASP retrievals.

\begin{tabular}{|c|c|c|c|c|}
\hline & & LIRIC & \multicolumn{2}{|c|}{ GRASP } \\
\hline Input & $\begin{array}{l}\frac{\text { Sun }}{\text { photometer* }} \\
\frac{- \text { AOD }}{- \text { VC }} \\
- \text { RRI and IRI } \\
-\% \text { sphericity }\end{array}$ & $\begin{array}{l}\frac{\text { Lidar }}{\text { Elastic backscattered }} \\
\text { signal: } \\
-355,532 \text { and } 1064 \mathrm{~nm} \\
-532 \text { cross-polarized } \\
\text { signal }\end{array}$ & $\begin{array}{l}\frac{\text { Sun }}{\text { photometer }} \\
\frac{- \text { AOT or AOD }}{\text { - Total scattered }} \\
\text { radiances } \\
\text { At } 440,670,870 \text { and } 1020 \mathrm{~nm}\end{array}$ & $\begin{array}{l}\frac{\text { Lidar }}{\text { Elastic backscattered }} \\
\text { signal: } \\
-355,532 \text { and } \\
1064 \mathrm{~nm}\end{array}$ \\
\hline Output & \multicolumn{2}{|c|}{ - VC profile for fine and coarse mode } & $\begin{array}{l}\text { Columnar (fine and coarse) } \\
- \text { PSD } \\
- \text { RRI and IRI } \\
- \text { VC } \\
-r_{\text {eff }} \\
- \text { SSA } \\
- \text { LR } \\
-\% \text { sphericity (total) }\end{array}$ & $\begin{array}{l}\text { Vertical (fine and coarse) } \\
-\mathrm{VC} \\
-\alpha \text { and } \beta \\
- \text { SSA }\end{array}$ \\
\hline
\end{tabular}

* AERONET product.

the submicron range. The wing-mounted Forward Scattering Spectrometer Probe (FSSP-300) with an accuracy of $30 \%$ (Baumgardner et al., 1992) and the in-cabin GRIMM OPC (sky OPC 1.129) with an accuracy of $10 \%$ (Denjean et al., 2016) were used to measure the optical size distributions in the diameter nominal size range between 0.28 and $20 \mu \mathrm{m}$ and between 0.3 and $32 \mu \mathrm{m}$, respectively. The total particle volume concentrations in the diameter range $0.1-30 \mu \mathrm{m}$ and volume concentrations of fine $(0.1-1 \mu \mathrm{m})$ and coarse $(1-30 \mu \mathrm{m})$ modes were calculated from the measured aerosol number size distributions, assuming that aerosol particles are spherical.

In addition, the nephelometer TSI (model 3563) was used to measure particle scattering coefficients at three wavelengths $(450,550$ and $700 \mathrm{~nm})$ with an accuracy of $5 \%$ (Müller et al., 2011) and a cavity attenuated phase shift (CAPS) was employed to obtain particle extinction coefficient at $530 \mathrm{~nm}$ with an accuracy of $3 \%$ (Massoli et al., 2010). Also, the PLASMA (Photomètre Léger Aéroporté pour la Surveillance des Masses d'Air) system, which is an airborne sun-tracking photometer, was used to obtain AOD with wide spectral coverage ( 15 channels between 0.34 and $2.25 \mu \mathrm{m}$ ) with an accuracy of approximately 0.01 (Karol et al., 2013), as well as the particle extinction vertical profiles (Torres et al., 2017).

\section{GRASP and LIRIC inversion algorithms}

The input information needed by the GRASP and LIRIC algorithms and the aerosol properties retrieved and used in this work are shown in Table 2. The LIRIC algorithm provides height-resolved aerosol VC data for the fine and coarse modes from combined lidar and sun-sky photometer information (Chaikovsky et al., 2008, 2012, 2016; Granados-
Muñoz et al., 2014). For this, column-integrated aerosol properties provided by the AERONET code (Dubovik et al., $2002,2006)$ are used as input, together with the lidar elastic backscatter signals at three different wavelengths $(355,532$, and $1064 \mathrm{~nm}$ ). These data are put through an iterative procedure based on the Levenberg-Marquardt method, which is described in detail in Chaikovsky et al. (2016). Besides the $\mathrm{VC}$, the algorithm retrieves additional datasets, including profiles of particle $\alpha$ and $\beta$ coefficients, and LR, among others. AERONET column-integrated products used as input are not modified by LIRIC during the retrieval process.

The GRASP inversion code (Dubovik et al., 2011; Lopatin et al., 2013) was developed at Laboratoire d'Optique Atmospherique (LOA) of the University of Lille. GRASP is based on a similar philosophy than LIRIC code but goes a step further since it simultaneously inverts both the coincident lidar and sun-sky photometer measurement, retrieving vertical, but also column, aerosol optical and microphysical properties for both fine and coarse modes. The simultaneous inversion of lidar and sun-sky photometer measurements is expected to improve the retrievals since the lidar data complement the sky photometer measurement at scattering angles of $180^{\circ}$ and the photometer data provide the information (e.g. amount and type) required for lidar retrievals that otherwise would be assumed from climatological data (Bovchaliuk et al., 2016). Therefore, the column aerosol properties obtained by GRASP will differ from the AERONET ones. Additionally, it is worth to note that GRASP allows independently retrieving aerosol optical and microphysical properties for the two distinct aerosol modes, fine and coarse. The retrieval of height-dependent SSA data is an additional advantage of GRASP over LIRIC. GRASP also provides an estimation of the systematic and random errors for both the directly retrieved (PSD, RRI, IRI, SSA) and derived $(\alpha, \beta$, 
(a)

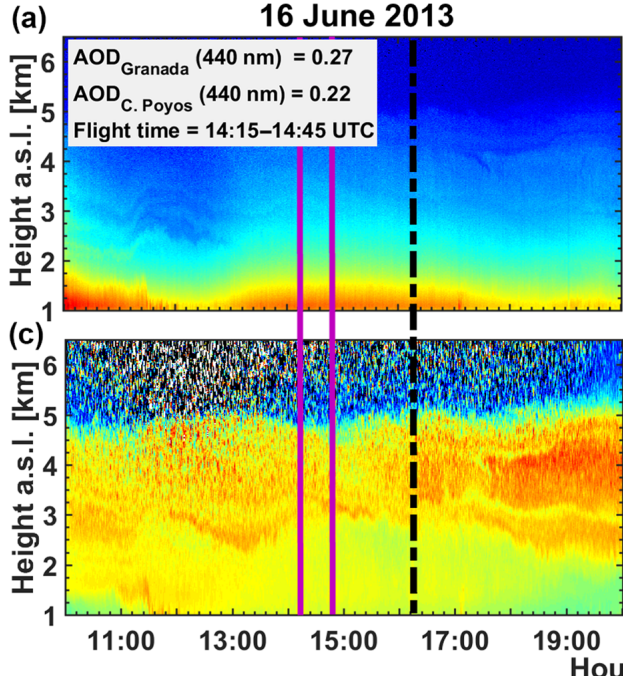

(b)

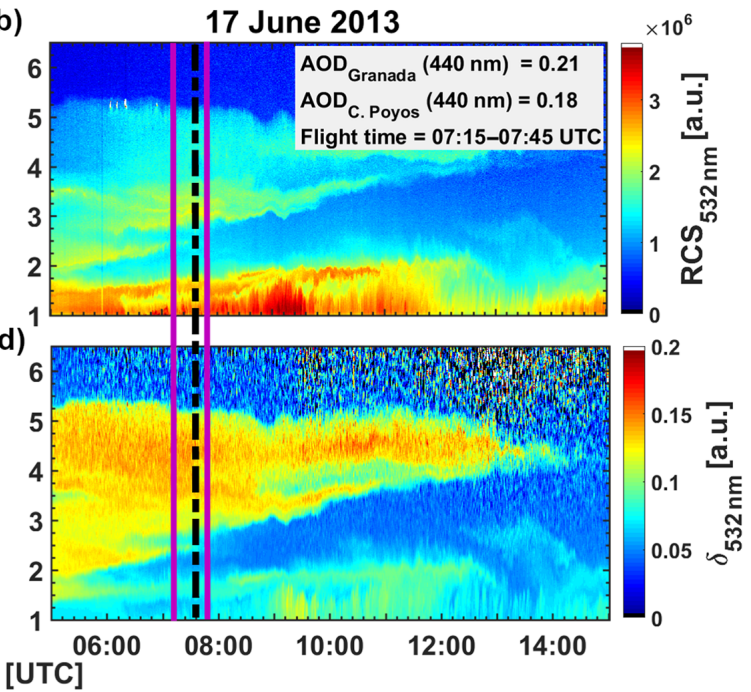

Figure 2. Temporal evolution of the lidar range-corrected signal (a, b) and the depolarization ratio (c, d) at $532 \mathrm{~nm}$ on 16 (a, c) and 17 (b, d) June 2013. The two purple lines indicate the lidar analysed interval. The black dashed line indicates the sun-photometer measurements.

VC profiles) aerosol properties. The SSA profiles errors are not shown because they are unfortunately not provided at the moment. Additional details on GRASP retrieval algorithm and its performance can be found in Lopatin et al. (2013) and Bovchaliuk et al. (2016).

\section{Results}

As previously mentioned, two of the ATR- 42 flights performed in the framework of ChArMEx-ADRIMED campaign, F30 and F31, were carried out over Granada on 16 and 17 June 2013, respectively. Figure 2 shows the time series of the lidar range-corrected signal (RCS) and the depolarization ratio $(\delta)$ at $532 \mathrm{~nm}$ on both days measured at Granada station. The RCS is calculated as $P \cdot r^{2}$, where $P$ is the lidar signal (corrected from background and dark current) and $r$ is the altitude. On the first day, a homogeneous layer is observed from the surface up to $5 \mathrm{~km}$ a.s.l., with an elevated aerosol layer coupled to the superficial aerosol layer throughout the day. The next day this layer was decoupled from the aerosol layer close to surface and disappeared around 13:00 UTC; measurements of $\delta$ showed that there was an aerosol type below $2.7 \mathrm{~km}$ a.s.l. and another aerosol type above this altitude, up to $5.5 \mathrm{~km}$ a.s.l. On 16 June, the lidar measurements (marked with purple lines in Fig. 2) obtained during the first flight between 14:15 and 14:45 UTC and sun-photometer measurements collected at 16:22 UTC (black dashed line in Fig. 2) at Granada and Cerro Poyos were selected for further analysis. The selected sun-photometer measurement was the closest measurement available in time to the first flight. On 17 June, the lidar measurements obtained during the second flight (07:15 to 07:45 UTC) and sun-sky photometer mea- surements obtained at both stations at 07:40 UTC were selected for further analysis.

AERONET products during these flights indicate the presence of dust particles. In fact, on 16 June $\mathrm{AOD}_{440}$ at 14:15 UTC was around 0.26 and 0.19 for Granada and Cerro Poyos, respectively, and 0.27 and 0.22 at 16:22 UTC. On this day, the $\mathrm{AE}_{440-870}$ was $0.30-0.26$ (Granada-Cerro Poyos) at 14:30 UTC and 0.34-0.27 (Granada-Cerro Poyos) at 16:22 UTC, indicating moderate atmospheric aerosol load dominated by coarse particles. On 17 June, the $\mathrm{AOD}_{440}$ at 07:40 UTC was 0.21 and 0.18 and the $\mathrm{AE}_{440-870}$ was 0.43 and 0.30 for Granada and Cerro Poyos, respectively, which also indicates the predominance of coarse particles on this day. The presence of mineral dust over Granada during both days is confirmed by the analysis of back-trajectory analysis (not shown) by HYSPLIT (Hybrid Single-Particle Lagrangian Integrated Trajectory; Stein et al., 2015; Rolph, 2016), which indicates that the relevant air masses came from the Saharan region, specifically from Algeria, at different heights.

\subsection{Comparison of columnar properties retrieved by GRASP and AERONET algorithms}

Some of the aerosol columnar properties obtained from AERONET and retrieved by GRASP (combining photometer and lidar measurements) on 16 and 17 June at Granada and Cerro Poyos stations are shown in Figs. 3-5 and summarized in Table 3.

Figure 3 shows the column-integrated PSD retrieved by both AERONET and GRASP algorithms on 16 and 17 June for Granada and Cerro Poyos stations. The retrieved PSD evidence the predominance of coarse mode particles, as expected for dust events (Lyamani et al., 2005; Guerrero- 
Table 3. Columnar effective radius and particle volume concentration for coarse and fine particle modes retrieved by GRASP and AERONET algorithms.

\begin{tabular}{|c|c|c|c|c|c|c|}
\hline & & & \multicolumn{2}{|c|}{16 June 2013} & \multicolumn{2}{|c|}{17 June 2013} \\
\hline & & & Granada & $\begin{array}{l}\text { Cerro } \\
\text { Poyos }\end{array}$ & Granada & $\begin{array}{l}\text { Cerro } \\
\text { Poyos }\end{array}$ \\
\hline \multirow{4}{*}{$\begin{array}{l}\text { Effective } \\
\text { radius } \\
(\mu \mathrm{m})\end{array}$} & GRASP & fine & 0.12 & 0.13 & 0.10 & 0.12 \\
\hline & & coarse & 2.2 & 2.2 & 2.4 & 2.2 \\
\hline & AERONET & fine & 0.12 & 0.11 & 0.11 & 0.12 \\
\hline & & coarse & 1.9 & 1.9 & 2.1 & 1.9 \\
\hline \multirow{4}{*}{$\begin{array}{l}\text { Volume } \\
\text { concentration } \\
\left(\mu \mathrm{m}^{3} \mu \mathrm{m}^{-2}\right)\end{array}$} & GRASP & fine & 0.018 & 0.017 & 0.018 & 0.011 \\
\hline & & coarse & 0.17 & 0.15 & 0.14 & 0.13 \\
\hline & AERONET & fine & 0.015 & 0.015 & 0.016 & 0.010 \\
\hline & & coarse & 0.14 & 0.13 & 0.12 & 0.11 \\
\hline
\end{tabular}
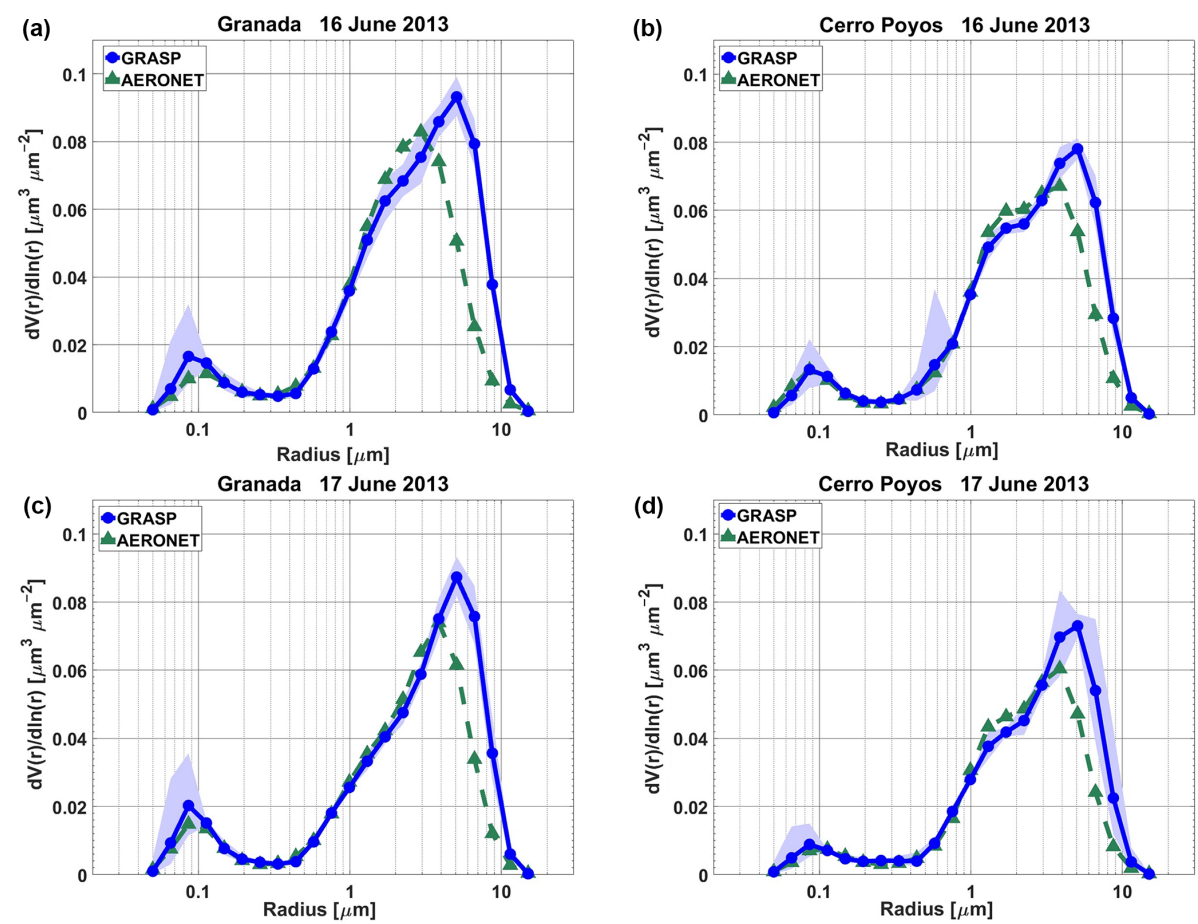

Figure 3. Size distribution retrieved by GRASP (blue) with its uncertainty (shaded area) and by AERONET (green) on 16 (a, b) and 17 (c, d) June 2013 at Granada $(\mathbf{a}, \mathbf{c})$ and Cerro Poyos $(\mathbf{b}, \mathbf{d})$.

Rascado et al, 2009). Both AERONET and GRASP retrieved PSD present a bimodal behaviour, with the radius of fine mode below $0.5 \mu \mathrm{m}$ and the radius of coarse mode above 0.5 $\mu \mathrm{m}$. The differences between the PSD retrieved by GRASP and AERONET are mostly within uncertainties associated with both methods $( \pm 10-35 \%$ for the size range from 0.1 to $7 \mu \mathrm{m}$ and $\pm 35-100 \%$ outside this range; Dubovik et al., 2000) except for the size range $5-8.7 \mu \mathrm{m}$, where the differences are higher, especially at $6.64 \mu \mathrm{m}(>100 \%)$. Furthermore, the coarse mode retrieved by GRASP over both sites shows a clear shift towards higher radii in comparison to the AERONET retrievals (Fig. 3). This shift was also observed by Lopatin et al. (2013) during dust and biomass burning events over Minsk, Belarus, and by Bovchaliuk et al. (2016) during dust events over Dakar, Senegal. These authors attributed this coarse mode shift towards higher radii to the use of the lidar data in the GRASP retrievals. The lidar data provide additional information at scattering angles of $180^{\circ}$ and further wavelengths compared to the sun photometer, influencing the size distribution retrieved especially in the coarse mode.

Table 3 summarizes the columnar $r_{\text {eff }}$ and VC of fine and coarse modes obtained at both stations by AERONET and GRASP algorithms on 16 and 17 June. The retrieved mi- 
(a)

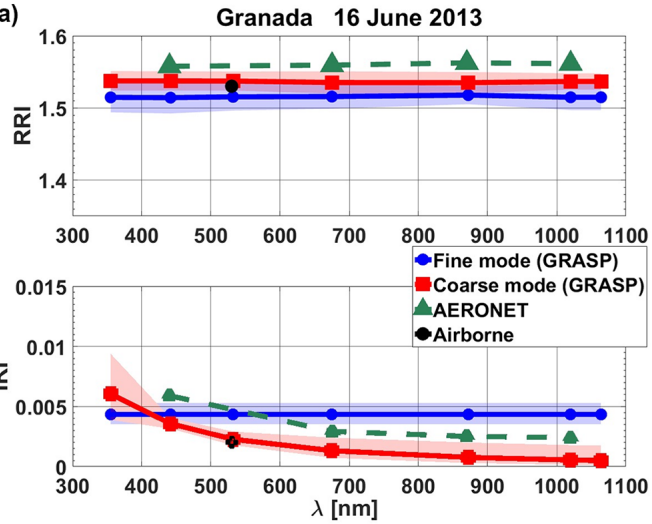

(c)

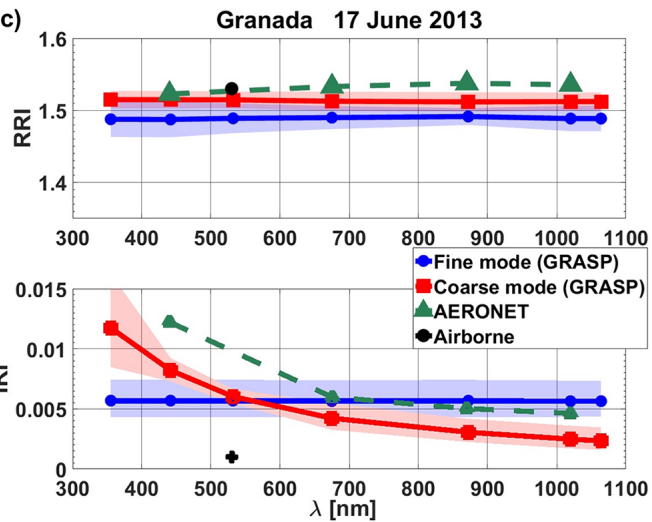

(b)
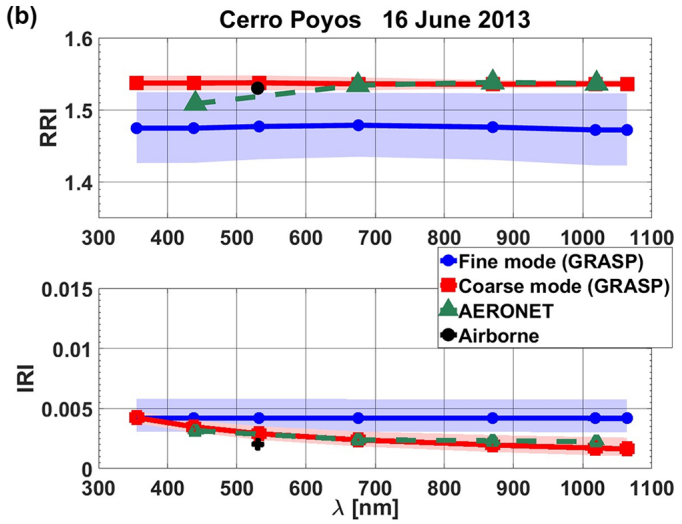

(d)
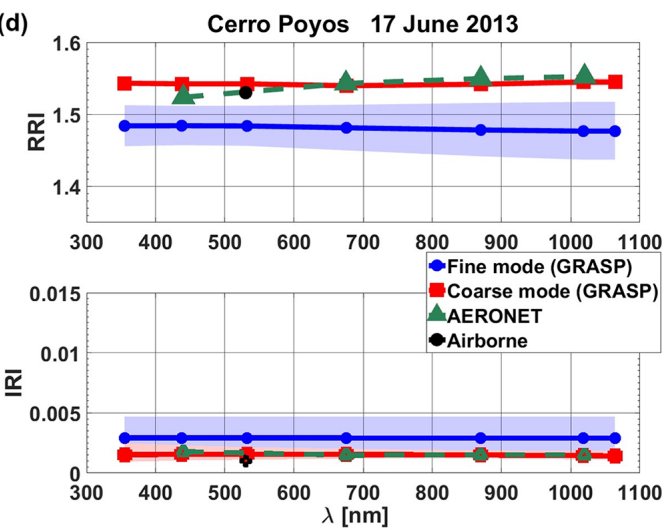

Figure 4. Spectral real (RRI) and imaginary (IRI) refractive indices retrieved by GRASP for the fine (blue) and coarse (red) modes with its uncertainty (shaded area), by AERONET (green) and by airborne measurement (black) on 16 (a, b) and 17 (c, d) June 2013 in Granada (a, c) and Cerro Poyos (b, d).

crophysical properties are similar to those typically obtained during African desert dust events over Granada (Valenzuela et al., 2012b). The fine mode $r_{\text {eff }}$ retrieved by both methods ranges between 0.10 and $0.13 \mu \mathrm{m}$. Differences between fine mode $r_{\text {eff }}$ retrieved by GRASP and AERONET are below $0.02 \mu \mathrm{m}$, which are within the uncertainty of the inversions (Lopatin et al., 2013; Torres et al., 2014). For the coarse mode, the $r_{\text {eff }}$ values obtained by GRASP were $0.03 \mu \mathrm{m}$ higher than those retrieved by AERONET but the differences are within the uncertainty range. A similar behaviour is observed for the column-integrated VC, with slightly larger values provided by GRASP for the fine and coarse modes $\left(0.016 \pm 0.003\right.$ and $\left.0.148 \pm 0.017 \mu \mathrm{m}^{3} \mu \mathrm{m}^{-2}\right)$ compared to AERONET $\left(0.014 \pm 0.003\right.$ and $\left.0.125 \pm 0.013 \mu \mathrm{m}^{3} \mu \mathrm{m}^{-2}\right)$, but differences are still within the uncertainties.

Figure 4 illustrates the retrieved columnar RRI and IRI for each day obtained by GRASP and AERONET at Granada and Cerro Poyos. Moreover, RRI and IRI at $530 \mathrm{~nm}$ estimated by Denjean et al. (2016) using airborne measurements over Granada on 16 and 17 June are included in the plot. AERONET provides RRI and IRI for the whole size distribution, while GRASP is able to provide RRI and IRI for fine and coarse modes separately. The RRI retrieved by GRASP and AERONET algorithms do not show any spectral wave- length variations, and the differences between RRI values retrieved by both inversion algorithms are within the uncertainties (differences below 5\%). Because of the predominance of the coarse mode during the analysed dust event, both the AERONET and airborne RRI values are close to the values retrieved by GRASP for the coarse mode, with differences $<0.03$, on both days. In contrast, the IRI values retrieved by GRASP for the fine mode present a rather low spectral dependence while IRI values for the coarse mode presents a clear increase in the UV region. These results are coherent with those reported for different absorption species by Schuster et al. (2016) using AERONET data. At Cerro Poyos we did not find the spectral dependence of the IRI typically associated with mineral dust. The AOD at $440 \mathrm{~nm}$ was around $0.18-0.27$ and we used AERONET Level 1.5 products; therefore, these values have large uncertainties ( $>50 \%$; Dubovik et al., 2000). The lack of spectral dependence can be just an artifact of the inversion. However, it is worthy to note that at Cerro Poyos the PSD shows a mode in the coarse mode size range around $1 \mu \mathrm{m}$. As there is still discussion in the scientific community about dust RI and about the differences in dust particles between different sources (e.g. Colarco et al., 2014), results can suggest possible differences in dust RI between long-range transported and mixture 

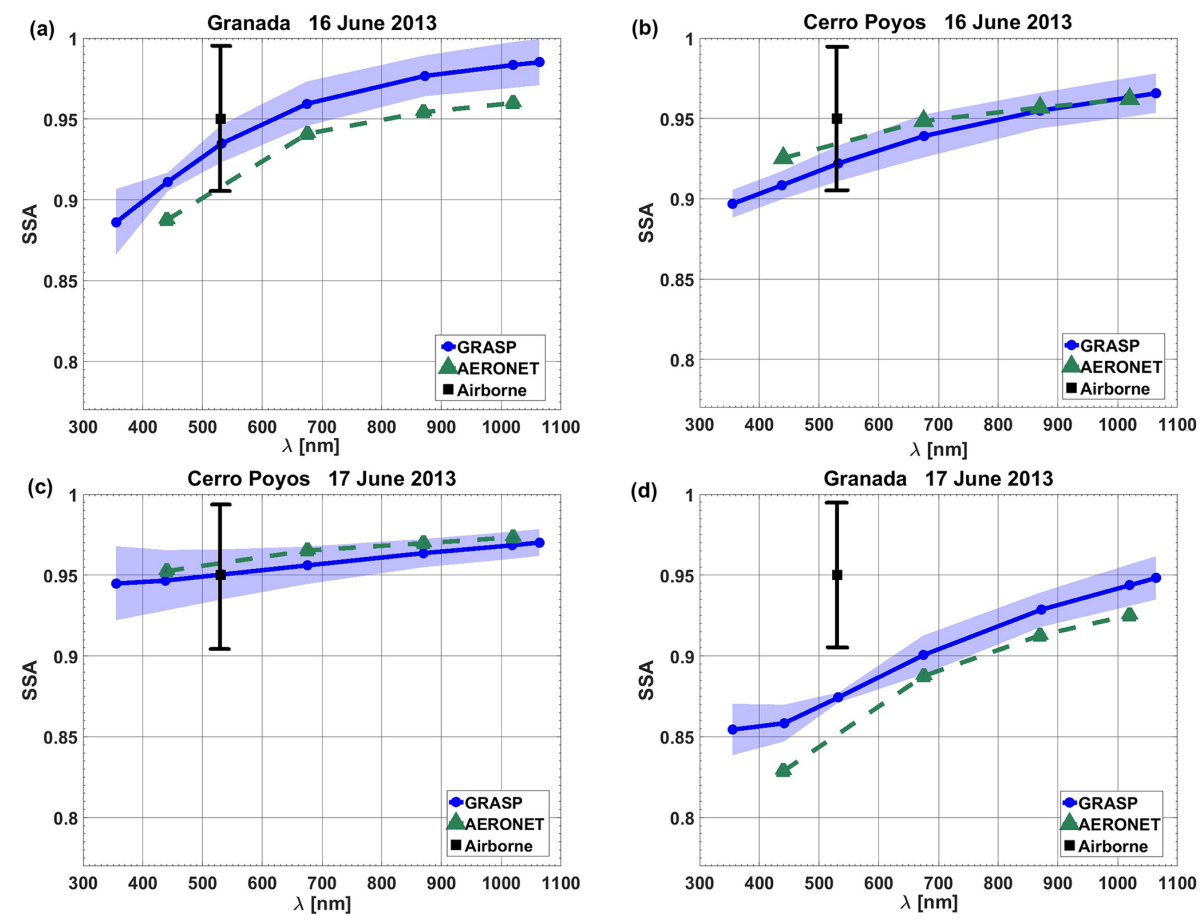

Figure 5. Single-scattering albedo retrieved by GRASP (blue) with its uncertainty (shaded area), by AERONET (green) and by airborne measurement (black) with its uncertainty on 16 (a, b) and 17 (c, d) June 2013 at Granada (a, c) and Cerro Poyos (b, d).

with local dust injections (the area is very dry in summer, thus favouring local mineral dust resuspension) and local pollution. The RRI and IRI values provided by AERONET show good agreement with GRASP retrievals for the coarse mode, something expected due to the large predominance of dust particles. Better agreement between IRI retrieved by AERONET and by GRASP for the coarse mode was found for Cerro Poyos, with differences $\sim 10 \%$, while for Granada these differences are between 35 and $80 \%$ (larger differences at lower wavelengths). The high discrepancy between IRI retrieved by AERONET and by GRASP in the case of Granada can be explained by the uncertainty associated with the incomplete lidar overlap. Cerro Poyos station is located above the lidar incomplete overlap height, and thus the effect of the incomplete overlap on the retrieval is negligible. This is not the case for the retrieval from Granada station. On 16 June, IRI airborne values estimated at $530 \mathrm{~nm}$ are close to IRI retrieved by GRASP at $532 \mathrm{~nm}$ for the coarse mode, and the differences are within the associated uncertainties. In contrast, on 17 June, there are more differences between IRI values retrieved by GRASP at Granada station and those estimated from airborne measurement, with differences over $100 \%$, whereas for the Cerro Poyos retrievals the differences are $50 \%$.

Figure 5 shows the columnar SSA values retrieved by GRASP and AERONET on 16 and 17 June at Granada and Cerro Poyos. Moreover, the SSA value at $530 \mathrm{~nm}$ calculated by Denjean et al. (2016) for dust layers using airborne mea- surements during the campaign was $0.95 \pm 0.04$. SSAs retrieved by GRASP at $532 \mathrm{~nm}$ are close to the airborne value. Better agreement with this value is found for the retrievals from Granada on 16 June and at Cerro Poyos on 17 June. The differences from Granada on 17 June could be due to the fact that the in situ value was calculated for the dust layer whereas GRASP and AERONET use sun-photometer data, which measure the total atmospheric column. Furthermore, in the case of Granada station, these measurements could be influenced by injections of local pollution. The retrieved SSA values are in the range of $0.85-0.98(355-1064 \mathrm{~nm}$ wavelength range), the typical values for dust aerosols (Dubovik et al., 2002; Toledano et al., 2011; Lopatin et al., 2013). Both AERONET and GRASP retrievals follow the same pattern with wavelength, with increasing SSA as wavelength increases, which is a typical characteristic of dust aerosols (Dubovik et al., 2002; Valenzuela et al., 2012b). Differences between SSA retrieved by AERONET and GRASP algorithms are below 0.03 at all wavelengths, within the uncertainties associated with each method. The discrepancies between SSA retrieved by AERONET and GRASP algorithms are obtained for Cerro Poyos station $(<1 \%)$ at $1020 \mathrm{~nm}$ in particular, whereas for Granada retrievals the differences are bigger and the lowest discrepancies are obtained at $675 \mathrm{~nm}$. 

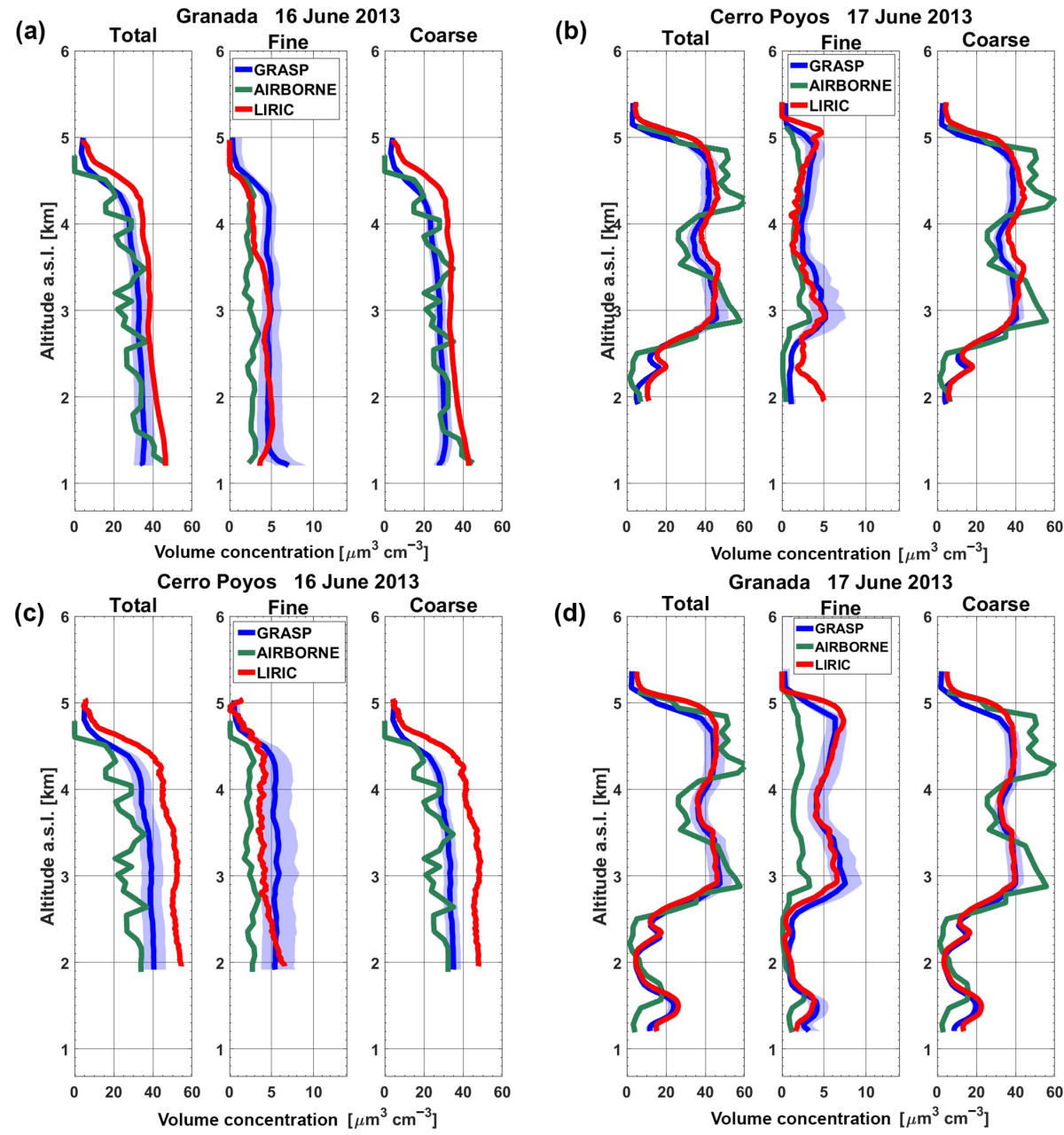

Figure 6. Volume concentration profile (total, fine and coarse mode) retrieved by GRASP (blue) with its uncertainty (shaded area), aircraft measurements (green) and LIRIC (red) on 16 (a, b) and 17 (c, d) June 2013 at Granada (a, c) and Cerro Poyos (b, d).

\subsection{Comparison of vertical properties retrieved by GRASP and LIRIC algorithms and in situ airborne measurements}

Figure 6 shows particle VC profiles for the fine, coarse and total (fine + coarse) modes, retrieved by GRASP and LIRIC, together with the results obtained with airborne instrumentation. Generally, there is good agreement between the profiles retrieved by GRASP and LIRIC and those obtained by the airborne instrumentation, with both retrievals and the airborne data reproducing similar vertical structures on both days. The airborne data show a larger variability compared to GRASP and LIRIC mostly associated with their larger uncertainty and the fact that the airborne data are instantaneous measurements whereas the lidar data are on average over a 30 min period.

Table 4 summarizes the VC mean values and associated standard deviations retrieved from the in situ airborne measurements, GRASP and LIRIC profiles shown in Fig. 6.
Data are analysed only for those layers with total VC above $20 \mathrm{\mu m}^{3} \mathrm{~cm}^{-3}$ to avoid undesirable outliers for low aerosol loads. Hence for 16 June we analyse the layer between 1.2 and $4.5 \mathrm{~km}$ a.s.l., and for 17 June the analysed layer is from 2.6 to $5.0 \mathrm{~km}$ a.s.l. There is a slight contribution of the fine mode in the dust layers on both days, with values between $3 \mu \mathrm{m}^{3} \mathrm{~cm}^{-3}$ for the airborne data and $5.3 \mu \mathrm{m}^{3} \mathrm{~cm}^{-3}$ for LIRIC. In general, it is observed that the coarse mode contributes the most to the total $\mathrm{VC}$, which is expected due to the predominance of mineral dust. Coarse mode concentration values range between $28 \pm 4$ and $46 \pm 4 \mu \mathrm{m}^{3} \mathrm{~cm}^{-3}$ on 16 June and $35 \pm 5$ and $42 \pm 11 \mu^{3} \mathrm{~cm}^{-3}$ on 17 June, depending on the dataset considered. GRASP and LIRIC retrievals both overestimate the airborne data for the fine mode while they overestimate the total mode on 16 June and underestimate the total mode on 17 June using sun-photometer data at both Granada and Cerro Poyos stations. In the case of fine mode, the differences between the airborne and the retrievals are lower than $5 \mu \mathrm{m}^{3} \mathrm{~cm}^{-3}$ (about $80 \%$ ). The agree- 
Table 4. Comparison of fine, coarse and total mean volume concentration $\left(\mu \mathrm{m}^{3} \mathrm{~cm}^{-3}\right)$ retrieved by GRASP, measured by airborne and retrieved by LIRIC for dust layers on 16 June (up to $4.5 \mathrm{~km}$ a.s.1.) and 17 June (from 2.6 to $5.0 \mathrm{~km}$ a.s.1.).

\begin{tabular}{llrrrrr}
\hline \multirow{2}{*}{$\begin{array}{c}\text { Volume concentration } \\
\left(\mu \mathrm{m}^{3} \mathrm{~cm}^{-3}\right)\end{array}$} & \multicolumn{2}{c}{ 16 June 2013} & & \multicolumn{2}{c}{ 17 June 2013 } \\
\cline { 3 - 4 } \cline { 6 - 7 } & & Granada & $\begin{array}{r}\text { Cerro } \\
\text { Poyos }\end{array}$ & & Granada & $\begin{array}{r}\text { Cerro } \\
\text { Poyos }\end{array}$ \\
\cline { 3 - 4 } Fine & GRASP & $4.7 \pm 0.6$ & $5.5 \pm 0.3$ & & $5.5 \pm 1.3$ & $3.5 \pm 1.0$ \\
& AIRBORNE & $2.6 \pm 0.4$ & $2.6 \pm 0.4$ & & $1.9 \pm 0.6$ & $1.9 \pm 0.6$ \\
& LIRIC & $4.2 \pm 0.8$ & $4.6 \pm 1.0$ & & $5.3 \pm 1.3$ & $2.8 \pm 1.1$ \\
\hline Coarse & GRASP & $28 \pm 4$ & $32 \pm 4$ & & $35 \pm 7$ & $36 \pm 5$ \\
& AIRBORNE & $31 \pm 8$ & $27 \pm 5$ & & $41 \pm 11$ & $41 \pm 11$ \\
& LIRIC & $37 \pm 4$ & $46 \pm 4$ & & $35 \pm 5$ & $38 \pm 6$ \\
\hline \multirow{2}{*}{ Total } & GRASP & $33 \pm 4$ & $38 \pm 4$ & & $40 \pm 8$ & $39 \pm 6$ \\
& AIRBORNE & $33 \pm 8$ & $28 \pm 5$ & & $42 \pm 11$ & $42 \pm 11$ \\
& LIRIC & $41 \pm 5$ & $50 \pm 4$ & & $40 \pm 6$ & $41 \pm 6$ \\
\hline
\end{tabular}

ment for the coarse mode is high with differences lower than $6 \mu \mathrm{m}^{3} \mathrm{~cm}^{-3}(25 \%)$, except for the LIRIC inversion from Cerro Poyos on 16 June, where the difference is $19 \mu^{3} \mathrm{~cm}^{-3}$ (around $80 \%$ ). Both algorithms show the largest differences for the retrievals from Cerro Poyos on 16 June, whereas the differences for the retrievals from Granada for total and coarse mode are around 15 and $25 \%$ using GRASP and LIRIC, respectively. On 17 June for Granada retrieval, the differences between both algorithms and airborne data below $2 \mathrm{~km}$ a.s.l. could be explained because the flight was not exactly over Granada, as shown in Fig. 1, and differences are expected in the lower $2 \mathrm{~km}$ of the atmosphere because of the influence of the city. In the dust layer on 17 June, the differences are around $20 \%$ for coarse and total VC by both algorithms for Granada and Cerro Poyos stations. Differences between GRASP and LIRIC retrievals are below $30 \%$, well within the combined uncertainty from both retrievals. There are no accurate calculations of the uncertainty associated with LIRIC profiles, but it is estimated to be around $50 \%$ in cases of mineral dust (Granados-Muñoz et. al., 2016).

Figure 7 shows the aerosol $\beta$ coefficient profiles at 355 , 532 and $1064 \mathrm{~nm}$ retrieved by GRASP and the profiles calculated by Klett-Fernald method. The LR used in the Klett method is assumed constant for the entire profile and was computed by fitting the integral of the different extinction profiles to the measured AOD. However, GRASP uses both sun-sky radiances and the backscatter lidar data to provide LR values, both in column-integrated and vertical profiles. The GRASP LR values are close to the LR values used by Klett-Fernald method; these values are typical for Saharan dust measured over the south-eastern Spain (GuerreroRascado et al., 2009; Navas-Guzmán et al., 2013). Below $1.6 \mathrm{~km}$, the Klett retrieval at 355 showed unrealistic values probably associated with instrumental problems. However, for GRASP this problem does not appear, probably due to the combined used of lidar and sun-photometer data. The GRASP algorithm underestimates the values obtained by the Klett-Fernald method, except for the Cerro Poyos retrieval on 17 June, with larger differences for Granada retrievals. Nevertheless, the differences are within the uncertainties claimed for our system (approximately 30\%). The differences at the ultraviolet channel reached $19 \%$ and around $9 \%$ for Granada and Cerro Poyos retrievals, respectively. The discrepancies between backscatter coefficient profiles at $532 \mathrm{~nm}$ retrieved by GRASP and Klett-Fernald are around $16 \%$ for Granada retrieval on 16 June and $11 \%$ on 17 June and for Cerro Poyos retrievals on both days. In the case of backscatter coefficient profiles at $1064 \mathrm{~nm}$, the differences between both retrievals are close to $24 \%$ for Granada on 16 June and Cerro Poyos on 17 June, while for the other two cases the differences are the lowest $(6 \%)$.

The comparison between aerosol $\alpha$ coefficient profiles retrieved by GRASP and those measured by airborne instruments (CAPS and PLASMA) is shown in Fig. 8. Profiles retrieved by GRASP show good agreement with the CAPS data (measurements only on 16 June at $532 \mathrm{~nm}$ ), even with slightly higher values for GRASP of approximately $3 \pm 3 \mathrm{Mm}^{-1}(7 \%)$ and $9 \pm 5 \mathrm{Mm}^{-1}(18 \%)$ for the inversions from Granada and Cerro Poyos, respectively. GRASP extinction coefficient retrievals were larger than PLASMA measurements at all wavelengths, with larger differences at the ultraviolet channel $(\sim 50 \%)$. On 16 June, the differences for the ultraviolet channel are $20 \pm 11 \mathrm{Mm}^{-1}(45 \%)$ and for the visible and ultraviolet channels are $11 \pm 8 \mathrm{Mm}^{-1}$ (30 and $40 \%$, respectively). These differences were similar or lower than those obtained by Karol et al. (2013) when comparing PLASMA with lidar data. On 17 June, PLASMA and GRASP show the same layers, but their differences are larger, reaching $50 \%$ for the visible channel and more than $60 \%$ for the ultraviolet and infrared channels. As GRASP 
(a)

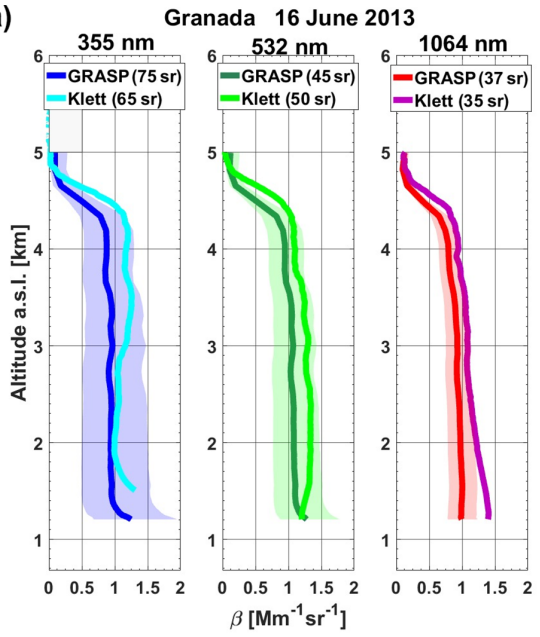

(c)

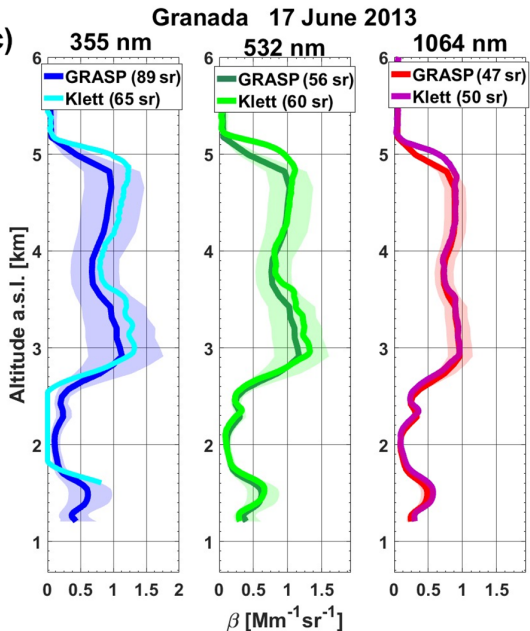

(b)

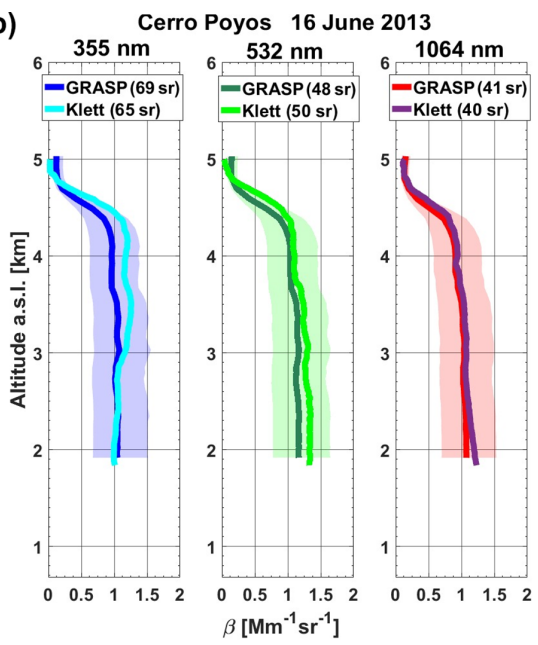

(d)

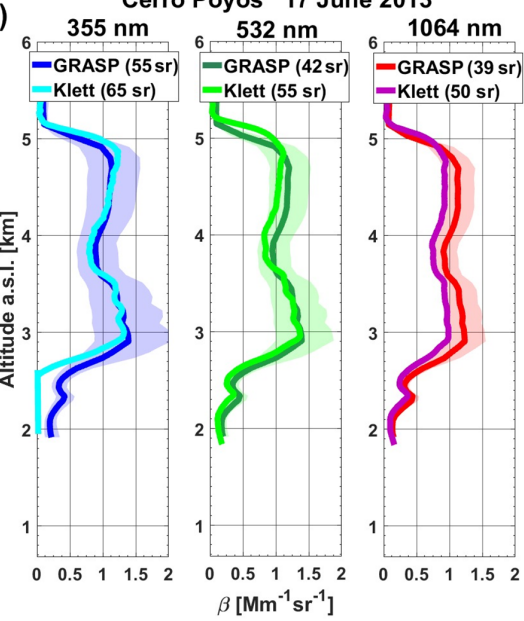

Figure 7. Aerosol backscatter coefficient profiles retrieved at 355,532 and $1064 \mathrm{~nm}$ by GRASP with its uncertainty (shaded area) and Klett-Fernald on 16 (a, b) and 17 (c, d) June 2013 at Granada (a, c) and Cerro Poyos (b, d).

and LIRIC reproduce the same layer structures for volume concentrations, these differences can be mainly associated with PLASMA.

Vertical profiles of SSA obtained by GRASP at Granada and Cerro Poyos station on 16 and 17 June are shown in Fig. 9. As SSA is an intensive aerosol parameter, only SSA values for the layers with large aerosol loads are represented. On 16 June, there are no remarkable changes in SSA with altitude, which agrees with the extinction and backscatter coefficients profiles and with the particle volume concentrations. For 17 June, vertical profiles of SSA are sensitive to the different aerosol layers with different aerosol types illustrating the capabilities of GRASP for detecting different aerosol layers with different composition. Nonetheless, the values of SSA are also within those associated with dust aerosol in previous studies (Dubovik et al., 2002; Toledano et al., 2011; Lopatin et al., 2013). Differences are observed again between the SSA profiles obtained at Granada and Cerro Poyos stations. On 16 June SSA differences between both retrievals are lower than $2 \%$ while on 17 June differences reach up to $10 \%$. This result is again associated with overlap issues, although the influence of the city, i.e. injection of large amounts of particles confined below the altitude of Cerro Poyos, cannot be neglected in sky radiance measurements.

Figure 10 shows scattering AE computed between 450 and $700 \mathrm{~nm}, \mathrm{AE}_{\text {sca }}(450-700)$, obtained by GRASP algorithm at Granada and Cerro Poyos stations together with those obtained from nephelometer airborne measurements. GRASP scattering coefficient profiles are calculated by multiplying the extinction coefficient by the SSA at the same wavelength. Despite the fact that the $\mathrm{AE}_{\mathrm{sca}}(450-700)$ profiles from the airplane date are noisier than GRASP profiles, general good agreement is observed, with discrepancies within the uncertainties. In general, GRASP values are larger than the airborne data for altitudes above $2.5 \mathrm{~km}$ a.s.l. Above this altitude, the $\mathrm{AE}_{\text {sca }}(450-700)$ values are close to zero for the airborne data on both days, which is typical of aerosols dom- 
(a)

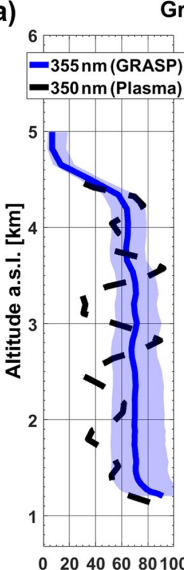

Granada 16 June 2013

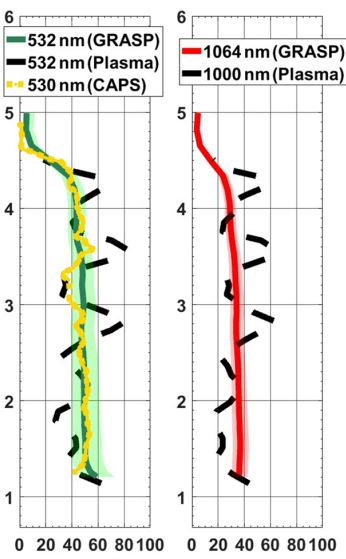

$\alpha\left[\mathrm{Mm}^{-1}\right]$

(c)

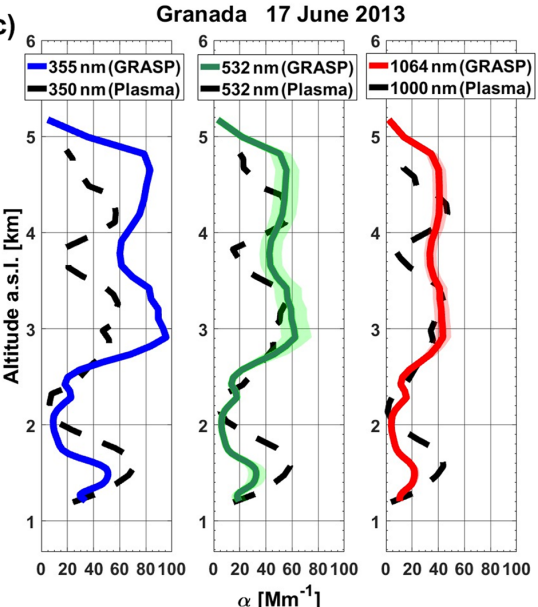

(b)

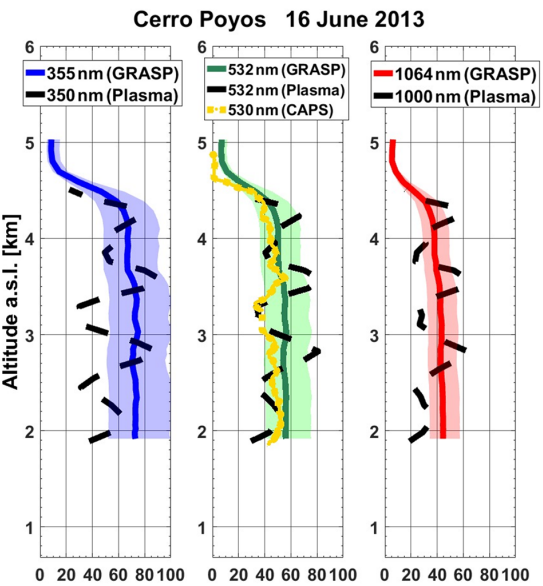

$\alpha\left[\mathrm{Mm}^{-1}\right]$

(d)

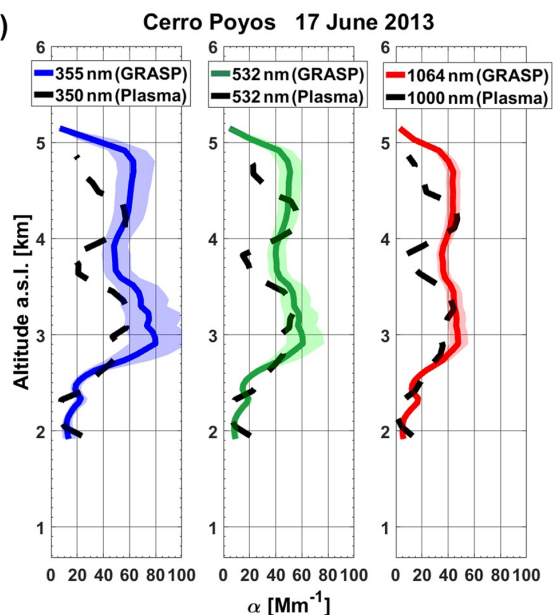

Figure 8. Aerosol extinction coefficient profiles retrieved by GRASP (355, 532 and $1064 \mathrm{~nm}$ ) with its uncertainty (shaded area), PLASMA $(350,530$ and $1000 \mathrm{~nm})$ and CAPS $(530 \mathrm{~nm})$ on $16(\mathbf{a}, \mathbf{b})$ and $17(\mathbf{c}, \mathbf{d})$ June 2013 at Granada (a, c) and Cerro Poyos (b, d).

inated by coarse particles (Bergstrom et al., 2007). However, in the lower part of the profiles $\mathrm{AE}_{\mathrm{sca}}(450-700)$ values are larger $(\sim 0.7$ and $\sim 1.6$ for the airborne data on 16 and 17 June, respectively) and GRASP profiles underestimate the airborne data. The values for these lower altitudes, including those retrieved by GRASP using the sun-photometer data measured at Granada and the airborne data, were similar to in situ measurements at IISTA-CEAMA, with values around $0.70 \pm 0.10$ and $1.67 \pm 0.07$ on 16 and 17 June, respectively. GRASP profiles have similar values above and below $2.5 \mathrm{~km}$ a.s.l. with better agreement between airborne data and Cerro Poyos retrieval. The Granada retrieval shows more differences on 17 June, the case with aerosol layers with different aerosol types. On 17 June, in the range of $\sim 1.8-2.7 \mathrm{~km}$ a.s.1., the aerosol load was low $\left(\sim 5 \mu \mathrm{m}^{3} \mathrm{~cm}^{-3}\right)$ and, hence, SSA and AE values could be less reliable in this layer. However, the layer up to $1.8 \mathrm{~km}$ a.s.l. showed a moderate concentration $\left(\sim 17 \mu \mathrm{m}^{3} \mathrm{~cm}^{-3}\right)$ with a different composition from layers above $2.7 \mathrm{~km}$ a.s.l., as shown by the SSA and AE profiles (Figs. 9 and 10, respectively).
Table 5. Mean value of backscatter Ångström exponent $(\beta-\mathrm{AE})$ and colour ratio (CR) between 532 and $1064 \mathrm{~nm}$, retrieved by GRASP for dust layers on 16 and 17 June 2013.

\begin{tabular}{lccccc}
\hline & \multicolumn{2}{c}{ 16 June 2013} & & \multicolumn{2}{c}{ 17 June 2013 } \\
\cline { 2 - 3 } \cline { 5 - 6 } & Granada & Granada & & Granada & Granada \\
\hline$\beta-\mathrm{AE}$ & $0.65 \pm 0.07$ & $0.46 \pm 0.05$ & & $0.63 \pm 0.12$ & $0.40 \pm 0.10$ \\
$\mathrm{CR}$ & $1.15 \pm 0.05$ & $1.13 \pm 0.05$ & & $1.09 \pm 0.09$ & $1.08 \pm 0.04$ \\
\hline
\end{tabular}

Finally, Table 5 shows the mean values with \pm 1 SD (standard deviation) of $\beta-\mathrm{AE} \mathrm{(532-1064)} \mathrm{and} \mathrm{colour} \mathrm{ratio}$ $(\mathrm{CR}=\beta(532 \mathrm{~nm}) / \beta(1064 \mathrm{~nm}))$ calculated by GRASP in the layer between 1.8 and $4.5 \mathrm{~km}$ a.s.l. and between 2.8 and $5.0 \mathrm{~km}$ a.s.l. on 16 and 17 June, respectively. The values of $\beta-\mathrm{AE}$ and $\mathrm{CR}$ are $0.5 \pm 0.2$ and $1.3 \pm 0.3$, respectively, which is in the range of typical values for dust aerosols (Perrone et al., 2014). 

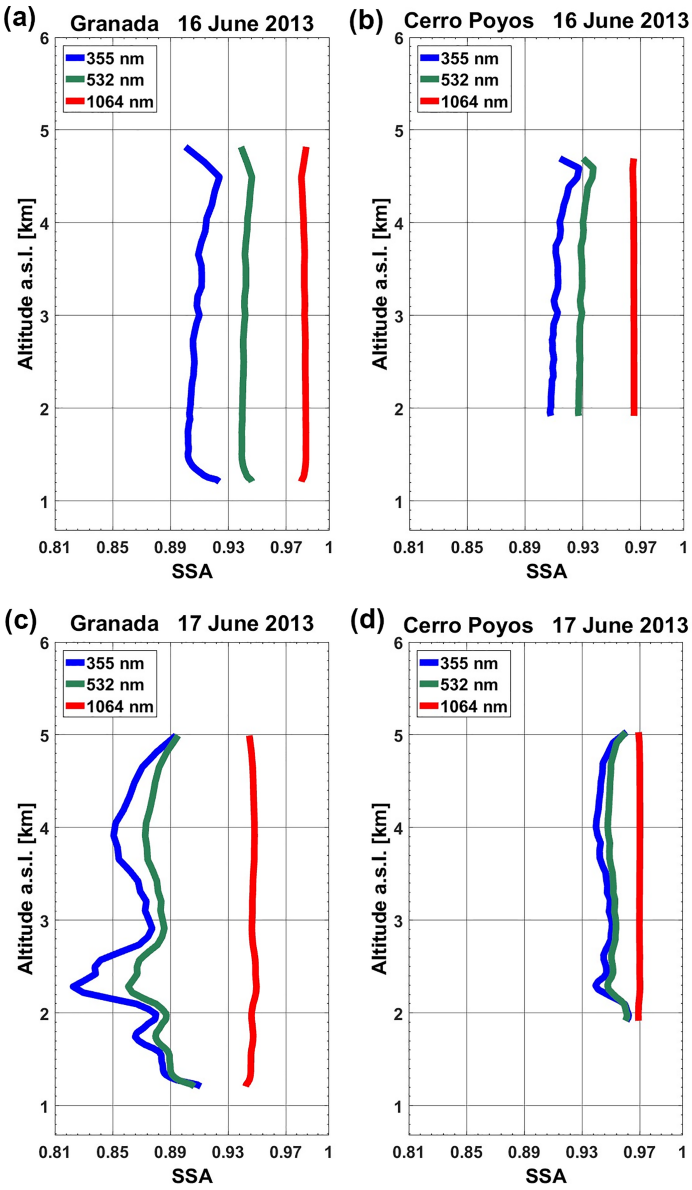

Figure 9. Single-scattering albedo profiles at 355, 532 and $1064 \mathrm{~nm}$ retrieved by GRASP on $16(\mathbf{a}, \mathbf{b})$ and 17 (c, d) June 2013 at Granada (a, c) and Cerro Poyos $(\mathbf{b}, \mathbf{d})$.

\section{Summary and conclusion}

The GRASP algorithm is applied to lidar and sun-sky photometer measurements at Granada during the ChArMExADRIMED campaign in summer 2013. Data from a second photometer at $1.2 \mathrm{~km}$ above the lidar system are also used, located above the lidar incomplete overlap height. This second sun photometer allows us to explore the effect of the lidar incomplete overlap on the retrievals and the influence of the aerosol vertical layering on the results, especially in cases of complex structures when different aerosol types are observed below and above Cerro Poyos. The optical and microphysical properties retrieved by GRASP using independent AERONET data have been compared with airborne measurements corresponding to two flights.

The flights took place on 16 and 17 June 2013, during dust events affecting Granada. The GRASP retrievals show a good agreement with AERONET products, with discrepancies well below the uncertainties. Total volume concentration profiles retrieved by GRASP and airborne measurements show a good agreement with differences around $15 \%$

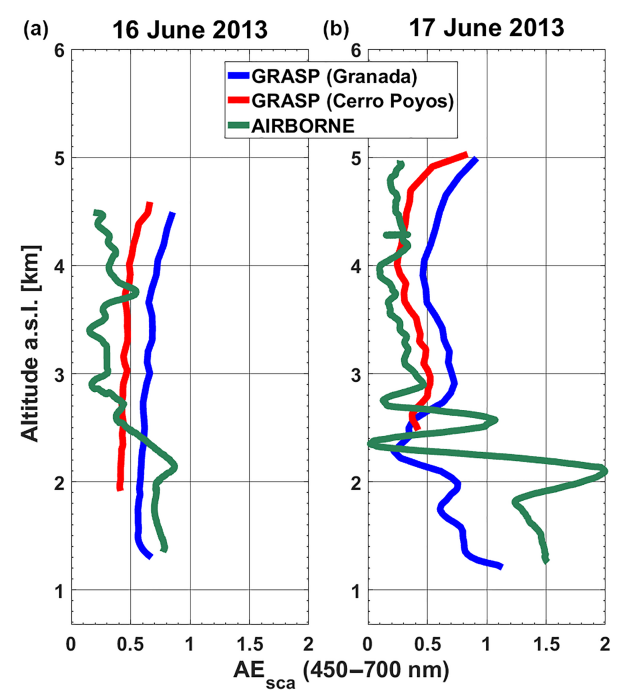

Figure 10. Scattering Ångström exponent (450-700 nm) retrieved by GRASP at Granada (blue) and Cerro Poyos (red) and aircraft measurements (green) on 16 (a) and 17 (b) June 2013.

on 16 June using for the retrieval sun-photometer data measured at Granada and on 17 June using for the retrieval sun-photometer data measured at Cerro Poyos. The agreement for the aerosol backscatter profiles with respect to those obtained using only lidar data and Klett-Fernald algorithm are quite good using both station data, showing differences below $12 \%$ at 355 and $532 \mathrm{~nm}$ for Cerro Poyos. In the case of the aerosol extinction profiles, good agreement was found between GRASP and the CAPS data (differences below $20 \%$ ), while the comparison with PLASMA data shows larger differences. The SSA profiles show values typical of dust aerosols and the differences between retrievals using sun-photometer data measured at Granada and Cerro Poyos are below $10 \%$ at the lidar wavelengths. Other aerosol properties obtained with GRASP, like the colour ratio and the backscatter AE, also show similar values to those observed in the literature for dust aerosols.

GRASP algorithm is quite robust as shows the agreement between the optical and microphysical properties retrieved by AERONET products and airborne measurements. Results obtained here show that the combination of lidar and sunphotometer data can provide improved and more complete column-integrated data compared to AERONET retrieval. Reliable vertically resolved properties such as the SSA, extinction or volume concentration are also provided, improving the capabilities of previous algorithms such as LIRIC.

Nonetheless, the retrieved scattering AE profiles together with the better agreement found between Cerro Poyos retrievals and the aircraft compared to Granada retrievals indicate that GRASP vertical distribution of some of the aerosol properties is still affected by considerable uncertainties. This is an expected result because of the use of the columnintegrated sun-photometer data. 
The analysis presented here is useful as a primary evaluation of the GRASP algorithm using sun photometer and lidar signal to retrieve aerosol microphysical properties, both integrated along the vertical column and as vertical profiles, and also to obtain the fine and coarse mode aerosol RI and SSA, which is not possible with the current AERONET inversion. The use of a second sun photometer located over the local atmospheric boundary layer can be very relevant for the study of the properties of aerosol layers with features different than the atmospheric boundary layer aerosol. However, the presented analysis is representative of Saharan dust transport to southern Europe, and still it is necessary to test a more complete dataset that includes different aerosol loads and types. In future studies, we could try to combine one lidar with two sun-sky photometers at different heights to try improving the retrievals in the cases with different aerosol layers. In addition, in order to validate the presented GRASP scheme, in the future we plan to use a database from global aerosol models (e.g. GEOS-5) following an approach similar to Whiteman et al. (2018).

Data availability. The data from lidar system of the Granada station can be accessed through the EARLINET database (see http: //access.earlinet.org/EARLINET/SearchPage.aspx). The data corresponding to column-integrated properties at Granada and Cerro Poyos can be obtained from the AERONET database (see https: //aeronet.gsfc.nasa.gov/). The aircraft data are available on the ChArMEx database (http://mistrals.sedoo.fr/ChArMEx/). GRASP inversion algorithm software used in this work is free and publicly available at http://www.grasp-open.com.

Competing interests. The authors declare that they have no conflict of interest.

Special issue statement. This article is part of the special issue "CHemistry and AeRosols Mediterranean EXperiments (ChArMEx) (ACP/AMT inter-journal SI"). It is not associated with a conference.

Acknowledgements. This work was supported by the Andalusia Regional Government through project P12-RNM-2409, by the Spanish Ministry of Economy and Competitiveness through project CGL2013-45410-R and CGL2016-81092-R and through grant FPI (BES-2014-068893), by the "Juan de la Cierva-Formación" program (FJCI-2014-22052) and the Marie Skłodowska-Curie Individual Fellowships (IF) ACE_GFAT (grant agreement no. 659398), and by the University of Granada through "Plan Propio. Programa 9 Convocatoria 2013". The financial support for EARLINET in the ACTRIS Research Infrastructure Project by the European Union's Horizon 2020 research and innovation programme through project ACTRIS-2 (grant agreement no. 654109). The authors thankfully acknowledge the FEDER program for the instrumentation used in this work and the Sierra Nevada National Park, for its support for the operation of Cerro Poyos station.

This work is part of the ChArMEx project supported by ADEME, CEA, CNRS-INSU and Météo- France through the multidisciplinary programme MISTRALS (Mediterranean Integrated STudies at Regional And Local Scales). We thank the instrument scientists, pilots and ground crew of SAFIRE for facilitating the instrument integration and conducting flight operations. Finally, the authors would like to acknowledge the use of GRASP inversion algorithm software (http://www.grasp-open.com) in this work.

Edited by: François Dulac

Reviewed by: two anonymous referees

\section{References}

Alados-Arboledas, L., Müller, D., Guerrero-Rascado, J. L., NavasGuzman, F., Pérez-Ramírez, D., and Olmo, F. J.: Optical and microphysical properties of fresh biomass burning aerosol retrieved by Raman lidar, and star-and sun-photometry, Geophys. Res. Lett., 38, L01807, https://doi.org/10.1029/2010g1045999, 2011.

Ansmann, A., Riebesell, M., Wandinger, U., Weitkamp, C., Voss, E., Lahmann, W., and Michaelis, W.: Combined Raman elastic backscatter LIDAR for vertical profiling of moisture, aerosol extinction, backscatter, and LIDAR ratio, Appl. Phys., B55, 18-28, https://doi.org/10.1007/BF00348608, 1992.

Barreto, Á., Cuevas, E., Granados-Muñoz, M.-J., AladosArboledas, L., Romero, P. M., Gröbner, J., Kouremeti, N., Almansa, A. F., Stone, T., Toledano, C., Román, R., Sorokin, M., Holben, B., Canini, M., and Yela, M.: The new sun-skylunar Cimel CE318-T multiband photometer - a comprehensive performance evaluation, Atmos. Meas. Tech., 9, 631-654, https://doi.org/10.5194/amt-9-631-2016, 2016.

Barreto, Á., Román, R., Cuevas, E., Berjón, A. J., Almansa, A. F., Toledano, C., González, R., Hernández, Y., Blarel, L., Goloub, P., Guirado, C., and Yela, M.: Assessment of nocturnal aerosol optical depth from lunar photometry at the Izaña high mountain observatory, Atmos. Meas. Tech., 10, 3007-3019, https://doi.org/10.5194/amt-10-3007-2017, 2017.

Baumgardner, D., Dye, J. E., Gandrud, B. W., and Knollenberg, R. G.: Interpretation of measurements made by the Forward Scattering Spectrometer Probe (FSSP-300) during the Airborne Arctic Stratospheric Expedition, J. Geophys. Res., 97, 8035-8046, https://doi.org/10.1029/91JD02728, 1992.

Bergstrom, R. W., Pilewskie, P., Russell, P. B., Redemann, J., Bond, T. C., Quinn, P. K., and Sierau, B.: Spectral absorption properties of atmospheric aerosols, Atmos. Chem. Phys., 7, 5937-5943, https://doi.org/10.5194/acp-7-5937-2007, 2007.

Böckmann, C.: Hybrid regularization method for the ill-posed inversion of multiwavelength lidar data to determine aerosol size distributions, Appl. Optics, 40, 1329-1342, 2001.

Boucher, O., Randall, D., Artaxo, P., Bretherton, C., Feingold, G., Forster, P., Kerminen, V.-M., Kondo, Y., Liao, H., Lohmann, U., Rasch, P., Satheesh, S. K., Sherwood, S., Stevens, B., and Zhang, X. Y.: Clouds and Aerosols, in: Climate Change 2013: The Physical Science Basis. Contribution of Working Group I to the Fifth Assessment Report of the Intergovernmental Panel on Climate Change, edited by: Stocker, T. F., Qin, D., Plattner, G.-K., Tig- 
nor, M., Allen, S. K., Boschung, J., Nauels, A., Xia, Y., Bex, V., and Midgley, P. M., Cambridge University Press, Cambridge, UK and New York, USA, 571-657, 2013.

Bovchaliuk, V., Goloub, P., Podvin, T., Veselovskii, I., Tanre, D., Chaikovsky, A., Dubovik, O., Mortier, A., Lopatin, A., Korenskiy, M., and Victori, S.: Comparison of aerosol properties retrieved using GARRLiC, LIRIC, and Raman algorithms applied to multi-wavelength lidar and sun/sky-photometer data, Atmos. Meas. Tech., 9, 3391-3405, https://doi.org/10.5194/amt-9-33912016, 2016.

Bravo-Aranda, J. A., Navas-Guzmán, F., Guerrero-Rascado, J. L., Pérez-Ramírez, D., Granados-Muñoz, M. J., and AladosArboledas, L.: Analysis of lidar depolarization calibration procedure and application to the atmospheric aerosol characterization, Int. J. Remote Sens., 34, 3543-3560, 2013.

Bravo-Aranda, J. A., Titos, G., Granados-Muñoz, M. J., GuerreroRascado, J. L., Navas-Guzmán, F., Valenzuela, A., Lyamani, H., Olmo, F. J., Andrey, J., and Alados-Arboledas, L.: Study of mineral dust entrainment in the planetary boundary layer by lidar depolarization technique, Tellus B, 67, 26180, https://doi.org/10.3402/tellusb.v67.26180, 2015.

Cai, Y., Montague, D. C., Mooiweer-Bryan, W., and Deshler, T.: Performance characteristics of the ultra-high sensitivity aerosol spectrometer for particles between 55 and $800 \mathrm{~nm}$ : Laboratory and field studies, J. Aerosol Sci., 39, 759-769, 2008.

Calvo, A. I., Olmo, F. J., Lyamani, H., Alados-Arboledas, L., Castro, A., Fernández-Raga, M., and Fraile, R.: Chemical composition of wet precipitation at the background EMEP station in Víznar (Granada, Spain) (2002-2006), Atmos. Res., 96, 408-420, 2010

Chaikovsky, A., Dubovik, O., Goloub, P., Balashevich, N., Lopatsin, A., Karol, Y., Denisov, S., and Lapyonok, T.: Software package for the retrieval of aerosol microphysical properties in the vertical column using combined lidar/photometer data (test version), Technical Report, Institute of Physics, National Academy of Sciences of Belarus, Minsk, Belarus, 2008.

Chaikovsky, A., Dubovik, O., Goloub, P., Tanré, D.,Pappalardo, G., Wandinger, U., Chaikovskaya, L., Denisov, S., Grudo, Y., Lopatsin, A., Karol, Y., Lapyonok, T., Korol, M., Osipenko, F., Savitski, D., Slesar, A., Apituley, A., Arboledas, L. A., Binietoglou, I., Kokkalis, P., Granados Muñoz, M. J., Papayannis, A., Perrone, M. R., Pietruczuk, A., Pisani, G., Rocadenbosch, F., Sicard, M., De Tomasi, F., Wagner, J., and Wang, X.: Algorithm and software for the retrieval of vertical aerosol properties using combined lidar/radiometer data: dissemination in EARLINET, 26th International Laser and Radar Conference, Porto Heli, Greece, 2012.

Chaikovsky, A., Dubovik, O., Holben, B., Bril, A., Goloub, P., Tanré, D., Pappalardo, G., Wandinger, U., Chaikovskaya, L., Denisov, S., Grudo, J., Lopatin, A., Karol, Y., Lapyonok, T., Amiridis, V., Ansmann, A., Apituley, A., Allados-Arboledas, L., Binietoglou, I., Boselli, A., D’Amico, G., Freudenthaler, V., Giles, D., Granados-Muñoz, M. J., Kokkalis, P., Nicolae, D., Oshchepkov, S., Papayannis, A., Perrone, M. R., Pietruczuk, A., Rocadenbosch, F., Sicard, M., Slutsker, I., Talianu, C., De Tomasi, F., Tsekeri, A., Wagner, J., and Wang, X.: Lidar-Radiometer Inversion Code (LIRIC) for the retrieval of vertical aerosol properties from combined lidar/radiometer data: development and distribution in EARLINET, Atmos. Meas. Tech., 9, 1181-1205, https://doi.org/10.5194/amt-9-1181-2016, 2016.

Colarco, P. R., Nowottnick, E. P., Randles, C. A., Yi, B., Yang, P., Kim, K.-M., Smith, J. A., and Bardeen, C.: Impact of radiatively interactive dust aerosols in the NASA GEOS-5 climate model: Sensitivity to dust particle shape and refractive index, J. Geophys. Res., 119, 753-786, https://doi.org/10.1002/2013JD020046, 2014.

Córdoba-Jabonero, C., Sorribas, M., Guerrero-Rascado, J. L., Adame, J. A., Hernández, Y., Lyamani, H., Cachorro, V., Gil, M., Alados-Arboledas, L., Cuevas, E., and de la Morena, B.: Synergetic monitoring of Saharan dust plumes and potential impact on surface: a case study of dust transport from Canary Islands to Iberian Peninsula, Atmos. Chem. Phys., 11, 3067-3091, https://doi.org/10.5194/acp-11-3067-2011, 2011.

Denjean, C., Cassola, F., Mazzino, A., Triquet, S., Chevaillier, S., Grand, N., Bourrianne, T., Momboisse, G., Sellegri, K., Schwarzenbock, A., Freney, E., Mallet, M., and Formenti, P.: Size distribution and optical properties of mineral dust aerosols transported in the western Mediterranean, Atmos. Chem. Phys., 16, 1081-1104, https://doi.org/10.5194/acp16-1081-2016, 2016.

Dubovik, O. and King, M.: A flexible inversion algorithm for retrieval of aerosol optical properties from Sun and sky radiance measurements, J. Geophys. Res., 105, 20673-20696, https://doi.org/10.1029/2000JD900282, 2000.

Dubovik, O., Smirnov, A., Holben, B. N., King, M., Kaufman, Y. J., Eck, T. F., and Slutsker, I.: Accuracy assessments of aerosol optical properties retrieved from Aerosol Robotic Network (AERONET) sun and sky radiance measurements, J. Geophys. Res., 105, 9791-9806, 2000.

Dubovik, O., Holben, B., Eck, T., Smirnov, A., Kaufman, Y., King, M., Tanre, D., and Slutsker, I.: Variability of absorption and optical properties of key aerosol types observed in worldwide locations, J. Atmos. Sci., 59, 590-608, 2002.

Dubovik, O., Sinyuk, A., Lapyonok, T., Holben, B. N., Mishchenko, M., Yang, P., Eck, T. F., Volten, H., Munoz, O., Veihelmann, B., van der Zande, W. J., Leon, J.-F., Sorokin, M., and Slutsker, I.: Application of spheroid models to account for aerosol particle nonsphericity in remote sensing of desert dust, J. Geophys. Res., 111, D11208, https://doi.org/10.1029/2005JD006619, 2006.

Dubovik, O., Herman, M., Holdak, A., Lapyonok, T., Tanre, D., Deuze, J. L., Ducos, F., Sinyuk, A., and Lopatin, A.: Statistically-optimized inversion algorithm for enhanced retrieval of aerosol properties from spectral multi-angle polarimetric satellite observations, Atmos. Meas. Tech., 4, 975-1018, https://doi.org/10.5194/amt-4-975-2011, 2011.

Dulac, F.: An overview of the Chemistry-Aerosol Mediterranean Experiment (ChArMEx), European Geosciences Union General Assembly, Geophysical Research Abstracts Vol. 16, EGU201411441, 27 April-2 May 2014, Vienna, Austria, 2014.

Eck, T. F., Holben, B. N., Reid, J. S., Dubovik, O., Smirnov, A., O'Neill, N. T., Slutsker, I., and Kinne, S.: Wavelength dependence of the optical depth of biomass burning, urban, and desert dust aerosols, J. Geophys. Res., 104, 31333-31349, https://doi.org/10.1029/1999JD900923, 1999.

Fernald, F. G.: Analysis of atmospheric lidar observations - Some comments, Appl. Optics, 23, 652-653, 1984. 
Fernald, F. G., Herman, B. M., and Reagan, J. A.: Determination of aerosol height distributions by lidar, J. Appl. Meteorol., 11, 482-489, 1972.

Franke, K., Ansmann, A., Müller, D., Althausen, D., Wagner, F., and Scheele, R.: One-year observations of particle lidar ratio over the tropical Indian Ocean with Raman lidar, Geophys. Res. Lett., 28, 4559-4562, https://doi.org/10.1029/2001GL013671, 2001.

Granados-Muñoz, M. J., Guerrero-Rascado, J. L., Bravo-Aranda, J. A., Navas-Guzmán, F., Valenzuela, A., Lyamani, H., Chaikovsky, A., Wandinger, U., Ansmann, A., Dubovik, O., Grudo, J., and Alados-Arboledas, L.: Retrieving aerosol microphysical properties by Lidar-Radiometer Inversion Code (LIRIC) for different aerosol types, J. Geophys. Res., 119, 4836-4858, https://doi.org/10.1002/2013JD021116, 2014.

Granados-Muñoz, M. J., Bravo-Aranda, J. A., Baumgardner, D., Guerrero-Rascado, J. L., Pérez-Ramírez, D., Navas-Guzmán, F., Veselovskii, I., Lyamani, H., Valenzuela, A., Olmo, F. J., Titos, G., Andrey, J., Chaikovsky, A., Dubovik, O., Gil-Ojeda, M., and Alados-Arboledas, L.: A comparative study of aerosol microphysical properties retrieved from ground-based remote sensing and aircraft in situ measurements during a Saharan dust event, Atmos. Meas. Tech., 9, 1113-1133, https://doi.org/10.5194/amt9-1113-2016, 2016.

Guerrero-Rascado, J. L., Ruiz, B., and Alados Arboledas, L.: Multispectral Lidar characterization of the vertical structure of Saharan dust aerosol over southern Spain, Atmos. Environ., 42, 2668 2681, https://doi.org/10.1016/j.atmosenv.2007.12.062, 2008.

Guerrero-Rascado, J. L., Olmo, F. J., Avilés-Rodríguez, I., NavasGuzmán, F., Pérez-Ramírez, D., Lyamani, H., and Alados Arboledas, L.: Extreme Saharan dust event over the southern Iberian Peninsula in September 2007: active and passive remote sensing from surface and satellite, Atmos. Chem. Phys., 9, 84538469, https://doi.org/10.5194/acp-9-8453-2009, 2009.

Guerrero-Rascado, J. L., Landulfo, E., Antuña, J. C., Barbosa, H. M. J., Barja, B., Bastidas, A. E., Bedoya, A. E., da Costa, R. F., Estevan, R., Forno, R. N., Gouveia, D. A., Jimenez, C., Larroza, E. G., Lopes, F. J. S., Montilla-Rosero, E., Moreira, G. A., Nakaema, W. M., Nisperuza, D., Alegria, D., Múnera, M., Otero, L., Papandrea, S., Pawelko, E., Quel, E. J., Ristori, P., Rodrigues, P. F., Salvador, J., Sánchez, M. F., and Silva, A.: Latin American Lidar Network (LALINET) for aerosol research: diagnosis on network instrumentation, J. Atmos. Sol.-Terr. Phy., 138-139, $112-120,2016$

Grund, C. J. and Eloranta, E. W.: University of Wisconsin high spectral resolution lidar, Opt. Eng., 30, 6-12, https://doi.org/10.1117/12.55766, 1991.

Holben, B. N., Eck, T. F., Slutsker, I., Tanre, D., Buis, J. P., Setzer, A., Vermote, E., Reagan, J. A., Kaufman, Y. J., Nakajima, T., Lavenu, F., Jankowiak, I., and Smirnov, A.: AERONET-a federated instrument network a data archive for aerosol characterization, Remote Sens. Environ., 66, 1-16, 1998.

IPCC: Contribution of Working Group I to the Fifth Assessment Report of the Intergovernmental Panel on Climate Change, Summary for Policymakers in Climate Change, Stocker, Cambridge University Press, Cambridgen, 2013.

Karol, Y., Tanré, D., Goloub, P., Vervaerde, C., Balois, J. Y., Blarel, L., Podvin, T., Mortier, A., and Chaikovsky, A.: Airborne sun photometer PLASMA: concept, measurements, comparison of aerosol extinction vertical profile with lidar, Atmos. Meas. Tech., 6, 2383-2389, https://doi.org/10.5194/amt-6-2383-2013, 2013.

Klett, J. D.: Stable analytical inversion solution for processing lidar returns, Appl. Optics, 20, 211-220, 1981.

Klett, J. D.: Lidar inversion with variable backscatter/extinction ratios, Appl. Optics, 24, 1638-1643, 1985.

Lewis, J. R., Campbell, J. R., Welton, E. J., Stewart, S. A., and Haftings, P. C.: Overview of MPLNET version 3 cloud detection, J. Atmos. Ocean. Tech., 33, 2113-2134, 2016.

Lopatin, A., Dubovik, O., Chaikovsky, A., Goloub, P., Lapyonok, T., Tanré, D., and Litvinov, P.: Enhancement of aerosol characterization using synergy of lidar and sun-photometer coincident observations: the GARRLiC algorithm, Atmos. Meas. Tech., 6, 2065-2088, https://doi.org/10.5194/amt-6-2065-2013, 2013.

Lyamani, H., Olmo, F. J., and Alados-Arboledas, L.: Saharan dust outbreak over southeastern Spain as detected by sun photometer, Atmos. Environ., 39, 7276-7284, https://doi.org/10.1016/j.atmosenv.2005.09.011, 2005.

Lyamani, H., Olmo, F. J., Alcantara, A., and Alados-Arboledas, L.: Atmospheric aerosols during the 2003 heat wave in southeastern spain I: Spectral optical depth, Atmos. Environ., 40, 6453-6464, https://doi.org/10.1016/j.atmosenv.2006.04.048, 2006.

Lyamani, H., Fernández-Gálvez, J., Pérez-Ramírez, D., Valenzuela, A., Antón, M., Alados, I., Titos, G., Olmo, F. J., and Alados-Arboledas, L.: Aerosol properties over two urban sites in South Spain during an extended stagnation episode in winter season, Atmos. Environ., 62, 424-432, https://doi.org/10.1016/j.atmosenv.2012.08.050, 2012.

Mallet, M., Dulac, F., Formenti, P., Nabat, P., Sciare, J., Roberts, G., Pelon, J., Ancellet, G., Tanré, D., Parol, F., Denjean, C., Brogniez, G., di Sarra, A., Alados-Arboledas, L., Arndt, J., Auriol, F., Blarel, L., Bourrianne, T., Chazette, P., Chevaillier, S., Claeys, M., D’Anna, B., Derimian, Y., Desboeufs, K., Di Iorio, T., Doussin, J.-F., Durand, P., Féron, A., Freney, E., Gaimoz, C., Goloub, P., Gómez-Amo, J. L., Granados-Muñoz, M. J., Grand, N., Hamonou, E., Jankowiak, I., Jeannot, M., Léon, J.-F., Maillé, M., Mailler, S., Meloni, D., Menut, L., Momboisse, G., Nicolas, J., Podvin, T., Pont, V., Rea, G., Renard, J.-B., Roblou, L., Schepanski, K., Schwarzenboeck, A., Sellegri, K., Sicard, M., Solmon, F., Somot, S., Torres, B., Totems, J., Triquet, S., Verdier, N., Verwaerde, C., Waquet, F., Wenger, J., and Zapf, P.: Overview of the Chemistry-Aerosol Mediterranean Experiment/Aerosol Direct Radiative Forcing on the Mediterranean Climate (ChArMEx/ADRIMED) summer 2013 campaign, Atmos. Chem. Phys., 16, 455-504, https://doi.org/10.5194/acp-16455-2016, 2016.

Massoli, P., Kebabian, P. L., Onasch, T. B., Hills, F. B., and Freedman, A.: Aerosol light extinction measurements by Cavity Attenuated Phase Shift (CAPS) Spectroscopy: Laboratory validation and field deployment of a compact aerosol particle extinction monitor, Aerosol Sci. Tech., 44, 428-435, https://doi.org/10.1080/02786821003716599, 2010.

Miffre, A., David, G., Thomas, B., and Rairoux, P.: Atmospheric non-spherical particles optical properties from UV-polarization lidar and scattering matrix, Geophys. Res. Lett., 38, L16804, https://doi.org/10.1029/2011GL048310, 2011.

Müller, D., Wandinger, U., and Ansmann, A.: Microphysical particle parameters from extinction and backscatter lidar data by in- 
version with regularization: simulation, Appl. Optics, 38, 23582368, 1999.

Müller, D., Heinold, B., Tesche, M., Tegen, I., Althausen, D.: Amiridis, V., Amodeo, A., Ansmann, A., Alados-Arboledas, L., Balis, D., Comeron, A., D'Amico, G., Gerasopoulos, E., Guerrero-Rascado, J. L., Freudenthaler, V., Giannakaki, E., Heese, B., Iarlori, M., Mamouri, R. E., Mona, L., Papayannis, A., Pappalardo, G., Perrone, M. R., Pisani, G., Rizi, V., Sicard, M., Spinelli, N., and Tafuro, A.: EARLINET Observations of the 1422-May long-range dust transport event during SAMUM 2006: Validation of results from dust transport modelling, Tellus B, 61, 325-339, https://doi.org/10.1111/j.1600-0889.2008.00400.x, 2009.

Müller, T., Laborde, M., Kassell, G., and Wiedensohler, A.: Design and performance of a three-wavelength LED-based total scatter and backscatter integrating nephelometer, Atmos. Meas. Tech., 4, 1291-1303, https://doi.org/10.5194/amt-4-1291-2011, 2011.

Murayama, T., Müller, D., Wada, K., Shimizu, A., Sekiguchi, M., and Tsukamoto, T.: Characterization of Asian dust and Siberian smoke with multiwavelength Raman lidar over Tokyo, Japan in spring 2003, Geophys. Res. Lett., 31, L23103, https://doi.org/10.1029/2004GL021105, 2004.

Nakajima, T., Tonna, G., Rao, R., Boi, P., Kaufman, Y., and Holben, B.: Use of sky brightness measurements from ground for remote sensing of particulate polydispersions, Appl. Optics, 35, 26722686, https://doi.org/10.1364/AO.35.002672, 1996.

Navas-Guzmán, F., Guerrero-Rascado, J. L., and Alados-Arboledas, L.: Retrieval of the lidar overlap function using Raman signals, Opt. Pura Apl., 44, 71-75, 2011.

Navas-Guzmán, F., Bravo-Aranda, J., Guerrero-Rascado, J., Granados-Muñoz, M., and Alados-Arboledas, L.: Statistical analysis of aerosol optical properties retrieved by Raman lidar over Southeastern Spain, Tellus B, 65, 21234, https://doi.org/10.3402/tellusb.v65i0.21234, 2013.

Navas-Guzmán, F., Fernández-Gálvez, J., Granados-Muñoz, M. J., Guerrero-Rascado, J. L., Bravo-Aranda, J. A., and AladosArboledas, L.: Tropospheric wáter vapour and relative humidity profiles from lidar and microwave radiometry, Atmos. Meas. Tech., 7, 1201-1211, https://doi.org/10.5194/amt-7-1201-2014, 2014.

Olmo, F. J., Quirantes, A., Alcántara, A., Lyamani, H., and Alados-Arboledas, L.: Preliminary results of a non-spherical aerosol method for the retrieval of the atmospheric aerosol optical properties, J. Quant. Spectrosc. Ra., 100, 305-314, https://doi.org/10.1016/j.jqsrt.2005.11.047, 2006.

Olmo, F. J., Quirantes, A., Lara, V., Lyamani, H., and AladosArboledas, L.: Aerosol optical properties assessed by an inversion method using the solar principal plane for non-spherical particles, J. Quant. Spectrosc. Ra., 109, 1504-1516, 2008.

Ortiz-Amezcua, P., Guerrero-Rascado, J. L., Granados-Muñoz, M. J., Bravo-Aranda, J. A., and Alados-Arboledas, L.: Characterization of atmospheric aerosols for a long range transport of biomass burning particles from Canadian forest fires over the southern Iberian Peninsula in July 2013, Óptica Pura y Aplicada, 47, 4349, https://doi.org/10.1016/j.jqsrt.2007.12.019, 2014.

Ortiz-Amezcua, P., Guerrero-Rascado, J. L., Granados-Muñoz, M. J., Benavent-Oltra, J. A., Böckmann, C., Samaras, S., Stachlewska, I. S., Janicka, L., Baars, H., Bohlmann, S., and AladosArboledas, L.: Microphysical characterization of long-range transported biomass burning particles from North America at three EARLINET stations, Atmos. Chem. Phys., 17, 5931-5946, https://doi.org/10.5194/acp-17-5931-2017, 2017.

Pappalardo, G., Amodeo, A., Apituley, A., Comeron, A., Freudenthaler, V., Linné, H., Ansmann, A., Bösenberg, J., D’Amico, G., Mattis, I., Mona, L., Wandinger, U., Amiridis, V., AladosArboledas, L., Nicolae, D., and Wiegner, M.: EARLINET: towards an advanced sustainable European aerosol lidar network, Atmos. Meas. Tech., 7, 2389-2409, https://doi.org/10.5194/amt7-2389-2014, 2014.

Pérez-Ramírez, D., Lyamani, H., Olmo, F. J., Whiteman, D. N., and Alados-Arboledas, L.: Columnar aerosol properties from sun and -star photometry: statistical comparisons and day-to-night dynamic, Atmos. Chem. Phys., 12, 9719-9738, https://doi.org/10.5194/acp-12-9719-2012, 2012.

Pérez-Ramírez, D., Veselovskii, I., Whiteman, D. N., Suvorina, A., Korenskiy, M., Kolgotin, A., Holben, B., Dubovik, O., Siniuk, A., and Alados-Arboledas, L.: High temporal resolution estimates of columnar aerosol microphysical parameters from spectrum of aerosol optical depth by linear estimation: application to long-term AERONET and star-photometry measurements, Atmos. Meas. Tech., 8, 3117-3133, https://doi.org/10.5194/amt-83117-2015, 2015.

Pérez-Ramírez, D., Lyamani, H., Smirnov, A., O’Neill, N. T., Veselovskii, I., Whiteman, D. N., Olmo, F. J., Alados-Arboledas, L.: Statistical study of day and night hourly patterns of columnar aerosol properties using sun and star photometry, Proc. SPIE, 100001, 100010K, 2016.

Perrone, M. R., De Tomasi, F., and Gobbi, G. P.: Vertically resolved aerosol properties by multi-wavelength lidar measurements, Atmos. Chem. Phys., 14, 1185-1204, https://doi.org/10.5194/acp14-1185-2014, 2014.

Preißler, J., Wagner, F., Pereira, S. N., and Guerrero-Rascado, J. L.: Multiinstrumental observation of an exceptionally strong Saharan dust outbreak over Portugal, J. Geophys. Res., 116, D24204, https://doi.org/10.1029/2011JD016527, 2011.

Rolph, G. D.: Real-time Environmental Applications and Display sYstem (READY) Website (http://www.ready.noaa.gov), NOAA Air Resources Laboratory, College Park, MD, 2016.

Román, R., Torres, B., Fuertes, D., Cachorro, V. E., Dubovik, O., Toledano, C., Cazorla, A., Barreto, A., Bosch, J. L., Lapyonok, T., González, R., Goloub, P., Perrone, M. R., Olmo, F. J., de Frutos, A., Alados-Arboledas, L.: Remote sensing of lunar aureole with a sky camera: Adding information in the nocturnal retrieval of aerosol properties with GRASP code, Remote Sens. Environ., 196, 238-252, https://doi.org/10.1016/j.rse.2017.05.013, 2017.

Schuster, G. L., Dubovik, O., and Arola, A.: Remote sensing of soot carbon - Part 1: Distinguishing different absorbing aerosol species, Atmos. Chem. Phys., 16, 1565-1585, https://doi.org/10.5194/acp-16-1565-2016, 2016.

Shipley, S. T., Tracy, D. H., Eloranta, E. W., Trauger, J. T., Sroga, J. T., Roesler, F. L., and Weinman, J. A.: High Spectral ResolutionLidar to Measure Optical-Scattering Properties of Atmospheric Aerosols, 1.Theory and Instrumentation, Appl. Optics, 22, 37163724, https://doi.org/10.1364/AO.22.003716, 1983.

Stein, A. F., Draxler, R. R, Rolph, G. D., Stunder, B. J. B., Cohen, M. D., and Ngan, F.: NOAA's HYSPLIT atmospheric transport and dispersion modeling system, B. Am. Meteorol. Soc., 96, 2059-2077, 2015. 
Titos, G., del Águila, A., Cazorla, A., Lyamani, H., CasqueroVera, J. A., Colombi, C., Cuccia, E., Gianelle, V., Močnik, G., Alastuey, A., Olmo, F. J., and Alados-Arboledas, L.: Spatial and temporal variability of carbonaceous aerosols: Assessing the impact of biomass burning in the urban environment, Sci. Total Environ., 578, 613-625, https://doi.org/10.1016/j.scitotenv.2016.11.007, 2017.

Toledano, C., Wiegner, M., Groß, S., Freudenthaler, V., Gasteiger, J., Müller, D., Müller, T., Schladitz, A., Weinzierl, B., Torres, B., and O'neill, N. T.: Optical properties of aerosol mixtures derived from sun-sky radiometry during SAMUM-2, Tellus B, 63, 635648, https://doi.org/10.1111/j.1600-0889.2011.00573.x, 2011.

Torres, B., Dubovik, O., Toledano, C., Berjon, A., Cachorro, V. E., Lapyonok, T., Litvinov, P., and Goloub, P.: Sensitivity of aerosol retrieval to geometrical configuration of ground-based sun/sky radiometer observations, Atmos. Chem. Phys., 14, 847875, https://doi.org/10.5194/acp-14-847-2014, 2014.

Torres, B., Dubovik, O., Fuertes, D., Schuster, G., Cachorro, V. E., Lapionak, T., Goloub, P., Blarel, L., Barreto, A., Mallet, M., Toledano, C., and Tanré, D.: Advanced characterisation of aerosol size properties from measurements of spectral optical depth using the GRASP algorithm, Atmos. Meas. Tech., 10, 3743-3781, https://doi.org/10.5194/amt-10-3743-2017, 2017.

Valenzuela, A., Olmo, F. J., Lyamani, H., Antón, M., Quirantes, A., and Alados-Arboledas, L.: Classification of aerosol radiative properties during African desert dust intrusions over southeastern Spain by sector origins and cluster analysis, J. Geophys. Res., 117, D06214, https://doi.org/10.1029/2011JD016885, 2012a.

Valenzuela, A., Olmo, F. J., Lyamani, H., Antón, M., Quirantes, A., and Alados-Arboledas, L.: Analysis of the desert dust radiative properties over Granada using principal plane sky radiances and spheroids retrieval procedure, Atmos. Res., 104-105, 292-301, https://doi.org/10.1016/j.atmosres.2011.11.005, 2012b.
Veselovskii, I., Kolgotin, A., Griaznov, V., Müller, D., Wandinger, U., and Whiteman, D. N.: Inversion with regularization for the retrieval of tropospheric aerosol parameters from multiwavelength lidar sounding, Appl. Optics, 41, 3685-3699, https://doi.org/10.1364/AO.41.003685, 2002.

Wandinger, U. and Ansmann, A.: Experimental Determination of the Lidar Overlap Profile with Raman Lidar, Appl. Optics, 41, 511-514, https://doi.org/10.1364/AO.41.000511, 2002.

Whiteman, D. N., Melfi, S. H., and Ferrare, R. A.: Raman lidar system for the measurement of water vapor and aerosols in the Earth's atmosphere, Appl. Optics, 31, 3068-3082, https://doi.org/10.1364/AO.31.003068, 1992.

Whiteman, D. N., Pérez-Ramírez, D., Veselovskii, I., Colarco, P., and Buchard, V.: Retrievals of aerosol microphysics from simulations of spaceborne multiwavelength lidar measurements, J. Quant. Spectrosc. Ra., 205, 27-39, https://doi.org/10.1016/j.jqsrt.2017.09.009, 2018.

Wiedensohler, A., Birmili, W., Nowak, A., Sonntag, A., Weinhold,K., Merkel, M., Wehner, B., Tuch, T., Pfeifer, S., Fiebig, M.,Fjäraa, A. M., Asmi, E., Sellegri, K., Depuy, R., Venzac, H., Villani,P., Laj, P., Aalto, P., Ogren, J. A., Swietlicki, E., Williams,P., Roldin, P., Quincey, P., Hüglin, C., FierzSchmidhauser, R.,Gysel, M., Weingartner, E., Riccobono, F., Santos, S., Grüning,C., Faloon, K., Beddows, D., Harrison, R., Monahan, C., Jennings, S. G., O’Dowd, C. D., Marinoni, A., Horn, H.-G., Keck,L., Jiang, J., Scheckman, J., McMurry, P. H., Deng, Z., Zhao, C. S., Moerman, M., Henzing, B., de Leeuw, G., Löschau, G., and Bastian, S.: Mobility particle size spectrometers: harmonization of technical standards and data structure to facilitate high quality long-term observations of atmospheric particle number sized distributions, Atmos. Meas. Tech., 5, 657685, https://doi.org/10.5194/amt-5-657-2012, 2012. 